Eletronic Magazine: Time - Technical - Territory, V.3, N.1 (2012), 43:77 ISSN: 2177-4366

\title{
TERRITORY OF THE MARACATUS-NAÇÃO OF PERNAMBUCO: PRELIMINARY INTERPRETATION
}

\author{
CLEISON LEITE FERREIRA \\ Geógrafo, Mestrando em Geografia no Programa de Pós-Graduação em Geografia na Universidade \\ de Brasília - PPGGEA - UnB/ Professor da Secretaria de Estado de Educação do Distrito Federal \\ e-mail: cleiferreira@yahoo.com.br
}

\section{RAFAEL SANZIO ARAÚJO DOS ANJOS}

Geógrafo, Doutor em Informações Espaciais (EPUSP-BR/IRD-FR) / Pós-Doutorado em Cartografia Étnica (MRAC-Tervuren-Bélgica), Prof. Associado do Depto. de Geografia da Universidade de Brasília (UnB) / Diretor do Centro de Cartografia Aplicada - UnB.

Tel: 55 (61) 3107-7242 E-mail: cartografia@unb.br

Sites: www.ciga.unb.br / www.rafaelsanziodosanjos.com.br

\begin{abstract}
The "Maracatu-Nação" is an important cultural expression found in Pernambuco, Brasil, in the cities of Recife, Olinda, Jaboatão dos Guararapes and Igarassu. It was creatade by people of African origin from the elections and coronations of Kings and Queens chosen from lay brotherhoods that brought together a wide ethnic diversity between the sixteenth and nineteenth centuries. Despite the persecutions that the practices related to Africans suffered the MaracatuNação grew in number of adherents and groups and is considered icon identity of Pernambuco. If today it is accepted and represents the feeling of "being pernambucano" it was thanks to the struggles and strategies of the population of African origin who had to negotiate their space in the city that sets confrontational, exclusionary and racist, despite being the majority. We understand that the territory is the spatial dimension allows more understanding social dynamics in space, especially when it comes to a population historically excluded, but highly participant in the urban context. Their social practices that reflect both define territoriality in the suburbs as in central area of the Metropolitan Region of Recife, with its headquarters as the main territorial references, because they are embedded in communities and neighborhoods by creating social ties, sense of belonging and reaffirming their African heritage. In addition to being currently linked to AfricanBrazilian religions - Xango (Candomble), Umbanda e Jurema, defining religious territoriality from the everyday life to the days of Carnival, especially in the ritual "Silent Drums Night" what happens in honor of the ancestors or the "Eguns". Cartographic and photographic resources were used as forms of spatial and visual representations of Maracatus-Nation, allowing us to understand its historical and current dynamics in addition being effective tools for reading and interpretation of the territory.
\end{abstract}

KEYWORDS: Maracatus-Nação; Afro-Brazilian Culture; Territoriality; Population of African Origen, Afro-Brazilian Religions.

RESUMEN: El “Maracatu-Nação” es una importante manifestación cultural de Pernambuco, Brasil, en Recife, Olinda, Jaboatão dos Guararapes y Igarassu. Fue creado por personas de origen africano a partir de las elecciones y coronaciones de Reyes e Reinas elegidos en hermandades laicas que reunió a una gran diversidad étnica entre los siglos XVI e XIX. A pesar de la persecución que las práticas relacionadas con los africanos sufrieron el "Maracatu-Nação" crecido en número de adherentes y de los grupos y es considerado icono de la identidade de Pernambuco. Si hoy se acepta y se representa el sentimiento de "pernambucanidade" gracias a las luchas y estrategias de la 
población de origen africano que tuvo que negociar su espacio en la ciudad que es conflictiva, excluyente y racista, a pesar de ser la mayoría. Entendemos que el territorio es la dimensión espacial que nos permite entender mejor la dinámica social en el espacio, sobre todo cuando se trata de una población históricamente excluida, pero muy participante en el contexto urbano. Sus práticas sociales que reflejan tanto definir la territorialidad en el suburbios como en la zona central de la Región Metropolitana de Recife, que tengan su sede las referencias territoriales principales, debido a que están incrustados en las comunidades y barrios mediante la creación de lazos sociales, sentido de pertenencia, y reafirmando su herancia africana. Además de estar actualmente vinculado a la Shangó (Candomblé), Jurema y Umbanda (religiones afro-brasileñas), el hecho de que define desde territorialidad religiosa cotidiana hasta el día de carnaval, especialmente en el ritual de "La Noche de los Tambores Silenciosos”, lo que sucede em homenaje a los antepasados, llamados Eguns. Recursos cartográficos y fotográficos fueron utilizados como una forma de representación visual y espacial, que nos permite comprender la dinámica histórica y actual de los "Maracatus-Nação”, y son herramientas eficaces para la lectura e interpretación del territorio.

PALABRAS CLAVE: Maracatus-Nação; Cultura Afro-Brasileña; Territorialidad; Población de origen africana; Religiones Afro-Brasileñas.

RESUMO: O Maracatu-Nação é uma importante manifestação cultural pernambucana presente em Recife, Olinda, Jaboatão dos Guararapes e Igarassu. Foi criado pela população de matriz africana a partir das eleições e coroações de Reis e Rainhas escolhidos em irmandades leigas que congregavam uma grande diversidade étnica entre os séculos XVI e XIX. Apesar das perseguições que as práticas ligadas aos africanos sofreram, o Maracatu-Nação cresceu em quantidade de adeptos e de grupos e é considerado ícone de identidade pernambucana. Se hoje é aceito e representa o sentimento de "pernambucanidade” foi graças às lutas e às estratégias da população de origem africana que teve que negociar seu espaço na cidade que se configura conflituosa, excludente e racista, apesar de ser maioria. Entendemos que o território é a dimensão espacial que mais possibilita entender as dinâmicas sociais no espaço, principalmente quando se trata de uma população historicamente excluída, mas altamente participante do contexto urbano. Suas práticas sociais definem territorialidades que repercutem tanto nas periferias como na área central da Região Metropolitana do Recife, tendo suas sedes como as principais referências territoriais, pois estão inseridas em comunidades e bairros criando vínculos sociais, sentimento de pertencimento e reafirmando as suas heranças africanas. Além de estarem atualmente vinculados ao Xangô, à Jurema e à Umbanda, religiões afro-brasileiras, definindo territorialidades religiosas desde o cotidiano até os dias de carnaval, principalmente no ritual Noite dos Tambores Silenciosos que acontece em homenagem aos ancestrais, denominados Eguns. Foram utilizados como forma de representação espacial e visual dos Maracatus-Nação recursos cartográficos e fotográficos que permitem compreender a sua historicidade e a dinâmica atual, além de serem instrumentos eficazes de leitura e interpretação do território. 
PALAVRAS-CHAVE: Maracatus-Nação, Cultura Afro-brasileira, Territorialidades, População de Matriz Africana, Religiões Afro-brasileiras.

\section{THE TERRITORY OF THE MARACATU-NAÇÃO OF PERNAMBUCO: PRELIMINARY INTERPRETATION}

\section{INTRODUCTION}

In Brazil, in its vast territorial extension is possible to find a great diversity of cultural expressions built along the historical process of almost 500 years by the population of African origin. This is because not only the country of the sixteenth century, when the first ships came bringing Africans from different ethnic groups ${ }^{1}$, such as during the next 300 years both ethnic groups and their descendants, were signing up to be the majority in urban and rural spaces.

In the main ports of colonial and imperial period as Salvador, Recife and Rio de Janeiro, Africans, from different social practices of relationship with the space before the period of the diaspora and the associations that were available with the various ethnic groups, were defining institutions around the material and immaterial culture such as family, religion and religiosity, culinary, music, and others. The daily life of the towns were filled mainly by knowledge and practices arising from the population "acquired" in African lands to work as slave, however brought its historical, cultural and political legacy contributing in shaping society and space in the new lands and participated actively in urban and rural life. As much as they were placed in conditions of exclusion and "submission", which did not meant passivity and lethargy, the Africans were intimately present in homes, farms, streets, churches, which somehow allowed to enter their world views and create and (re)invent or redesign their own practices from Africa, as well as incorporating indigenous and European references. Despite the social structure that constituted the colonial space and it would unfold in complex spatial arrangements, with a center-periphery structure, the African population and African-Brazilian managed to act significantly not letting their identity and references to the ethnic and spatial African continent be lost.

This process establishes an important component of spatial analysis - the territory. It is the best instrument of knowledge of the practices of the population of African origin in Brazil, which, centuries ruled and subjugated, defined in the space its means of unity around ethnic and cultural aspects, endowing it with feelings of ownership, power of legitimacy from their material and nonmaterial heritage which affects spatially shaping an identity. Moreover, it is the territory where "are engraved the cultural and symbolic references of the population" (ANJOS, 2010, p. 7)

\footnotetext{
${ }^{1}$ The main ethnic references of the African continent brought to constitute the formation of the Brazilian territory were, as pointed out by Anjos (2010, p. 39): “Minas, Congos, Angolas, Anjicos, Luandas, Quetos, Hauças, Fulas, Uruás, Ijexás, Jalofos, Mandingas, Anagôs, Fons, Ardas, amongst many others.” This allows us to say that there was no uniformity with regard to culture, to the relationship with space and religions.
} 
and that is where "flow into all actions, all passions, all power, all strength, all the weaknesses" (SANTOS, 2006, p 13.) It is important to remember that Milton Santos made it clear that territory, one that carries life, social practices, material and spiritual exchanges, that is the used territory, "is the ground plus identity" (SANTOS, 2006, p 14).

The territory also allows to recognize the historical processes of social exclusion, particularly with regard to the headquarters of the most significant ethnic population and the expropriation of the spaces at the expense of lack of land for a large majority, setting up a space carved up into goods for a share holder privileges and inaccessible or precarious for others. Thus the territory bears the marks of past, the current dynamic, and lines of force that show what can happen in the future in space (ANJOS, 2010).

The actions of groups to secure and control their territory takes place through the social practices that define themselves as territoriality. According to Anjos (2011, p 16) "territoriality presents itself as the collective effort of a social group to consolidate their occupation, to maintain its environment and define their territory."

The objective of this article is to realize a geographic study of a cultural expression built by African-Brazilian population in Pernambuco, the Maracatu-Nação. This cultural manifestation, originating in the festivities of the coronation of the Kings of Congo, has over two hundred years of existence and is present in the Metropolitan Region of Recife, where possibly created identitary links and defined territories from cultural practices and ethnic aspects of African origin conforming territorialities.

We used Thematic Maps and Photographs as ways of representing, reading and interpretation of the territory, because they are important tools of work and research with regard to records of spatial dynamics, and should not be viewed as products with an end in themselves, but as instruments able to reveal the historicity of human action, its effects on the current moment and future projections.

It is noteworthy that, as shown by Anjos (2011), maps as graphical representation and interpretation of the real world are effective tools to enable reading of the territory and reveal the "territoriality of social constructions of space and natural features and therefore, the facts show geography and its conflicts." (ANJOS, 2011, pp. 16 e 17).

With regard to photography, Anjos claims to be an important documental resource to geographical knowledge because of the "representations and interpretations of time, space and society, which does not crystallize and are not static" (ANJOS, 2011, p.17). According to Anjos, the photographic record allows us to see in society, particularly with regard to the social structure of a cultural matrix, "if it is rich or poor, fair or discriminatory" (Idem). It may also be an important strategic instrument of knowledge of what really happens in the territory (ANJOS, 2011).

Eletronic Magazine: Time - Technical - Territory, V.3, N.1 (2012), 43:77 ISSN: 2177-4366 
Below we will present the historical formation of Maracatu-Nação in Pernambuco as a social construction of the population of African origin in Recife in different contexts, noting that its manifestations have taken different features over time that occurred from reinventions and strategies ensuring survival and continuity of their practices.

\section{THE ORIGENS OF MARACATU-NAÇÃO}

Among the many practices that have been reworked and that allowed the creation of new cultural expressions, there are the elections and coronations of Kings and Queens of the Congo, made by the Brotherhoods of the Rosary of Black Men in Brazil since at least 1666, in Pernambuco. The selection and coronation of a king and a queen among the associated groups in sororities also occurred in other states such as Bahia, Minas Gerais, Mato Grosso, Sao Paulo and Rio de Janeiro.

The brotherhoods or confraternities of the Rosary were lay associations encouraged by the Portuguese Court and the Catholic Church in Brazil, with the intention of maintaining an "order" among the African people and create the Catholic and devotional spirit, Christianizing them. In spite of allowing greater control over the enslaved Africans, they also served for the different ethnic groups associated with them to relate and affirm socially and culturally, as shown by Souza (2006). Participated in these fraternities and was very present in other social spaces in Brazil between the sixteenth and nineteenth centuries a wide variety of nations like Congo, Angola, Benguela, Mozambique, Minas, Cabinda, Cassenje, and others, which in themselves also carried various ethnic references thus should not be treated uniformly.

In Portugal, before the colonization of lands in Brazil and the African Diaspora to America there were already the lay brotherhoods, where it was observed that the "black" population was identified with several Catholic saints because the representation of skin color, as Saint Esleban, Saint Ephigenia, Saint Benedict, or objects which referred to the religious practices of African origin, such as the Rosary of Our Lady, which was parallel to the "Òpelè-Ifá" ${ }^{2}$, that led to the adoption of this saint and devotion to the Catholic worship among Africans, according to Tinhorão (2000). The brotherhoods in several Brazilian cities built churches dedicated to their patron saints, and these also often associated with the gods, the Orixas, who were brought by Africans. Thus, even integrating their beliefs and practices from their places of origin, the Church and the government allowed the Africans to associate and conduct their festivities to

\footnotetext{
${ }^{2}$ The Opele-Ifa, or "Rosary of Ifa" is a necklace used in the consultations on the future. Tinhorão (2000) suggests that the Rosary was adopted by Africans (mainly from Nigeria where was born the Yoruba worship) to cover up their traditional necklace, the Opele-Ifa, thus maintaining the practices of guessing the future, telling furtunes and the luck in love.
} 
maintain an apparent passivity in the face of the diaspora and slave labor that they were forced to live.

The fraternities or brotherhoods ruled on their compromises the election of kings and queens, and other authorities, among Africans, and it was very common in Brazil until the early nineteenth century. The choice led to a festive time with great music and dance in African style, to be held in the day of Our Lady of the Rosary, when occurred ownership of the positions and awaited Coronation of King and Queen elected. Both the election and the day of the coronation were often authorized by the Portuguese Court and supported by the Church because they thought being an ingenuous practice, and also because they could have in the elected people a form of social control of their "confreres" or "brothers", but sometimes these practices were curtailed, because they saw the possibility of mobilization and articulation of the black people.

Gradually, in Brazil, the brotherhoods were becoming extinct in the nineteenth century and with them the election and the coronations of Kings and Queens. Not by the hands of people of African origin, but from the action of the government of wanting to annihilate any practices of black people, claiming to be dirty and connected to the delay and disorder, using even the main newspapers in circulation to influence public opinion against the continuity of such events in the urban space. Despite the persecutions, the population of African origen while they watched their buildings dissolve hinged on their daily activities around the symbolism and significance of these institutions accounted for them. Overwhelm the social actors as naïve and destitute of creative ability was (and still is) the way in which slavocratic, aristocratic and republican elites in the past sought to wipe out any trace of Africanness in Brazilian society. They did not realize that while the culture takes root, it is not impervious to the changes of/in society.

It is noteworthy that was virtually "crystallized" go to church to pay homage to patrons spontaneously and not in an institutionalized way, except by people's own daily life, as they also create their extraordinary institutions, troubling governmental institutions, frightening them. The presence of Kings and Queens was also consolidated in social life. Undoubtedly the festive moments and organizations around the coronation, more than fulfill a social order, represented spaces for socialization, exchange of formal and informal knowledge about everyday life. In this sense is that such practices and social organizations both around the religiosity and the royalty within the ethnic groups became extinguished for the empire and the clergy, but not for the people who continued to hold their festivals and processions in honor to the saints of the brotherhoods, especially of Our Lady of the Rosary of Black Men Brotherhood (GUILLEN, 2008, p. 185).

Nowadays, in several Brazilian states, can be found many cultural expressions from the old celebrations of coronations of Kings and Queens such as Congadas, Terno de Reis, Moçambiques, Reis Congo, Reisados, Cambindas, Aruendas, and Maracatus. These typologies were gradually Eletronic Magazine: Time - Technical - Territory, V.3, N.1 (2012), 43:77 ISSN: 2177-4366 
taking shape and becoming traditions in each place where the old coronations took place, adapting to different historical, social and political contexts, both with respect to the government such as the church. This is because these events had become parties and processions of the lay population, not always carried out by the high clergy, in honor of the saints of African-Brazilian population devotion. And in many cases, the expressions started to relate to religions of African origin, such as Candomblé, Xango, Umbanda, and Jurema.

In Recife, many of these festivities and processions in honor of Our Lady of the Rosary took place accompanied by black men and women, divided into "nations" which walked through the city streets. Each nation had its own king and queen who were covered by a large colorful umbrella. They were a royal court that accommodated a large number of people as members or were taking a prominent position, or accompanying the act by singing, dancing or playing musical instruments. These events present in the urban space of Recife since the first years of the nineteenth century were gradually called Maracatu-Nação.

The Maracatu-Nação grown in number of "nations" and followers in various cities of the Metropolitan Region of Recife (RMR), having its headquarters located in poor communities in central and peripheral areas. Currently Maracatu-Nação is known as the main cultural manifestation of Pernambuco and is the icon of Recife identity, excelling in events throughout the year and particularly during the carnival, performing the official opening of the popular party.

In the following item will be presented the cartography of the "Maracatus-Nação" and its relationship with the city of Recife from the spatial distribution of their seats, allowing not only the visualization of the distribution of this manifestation, but also the contexts that were defining their territories and which reading can be done with the map as a graphical representation of their spatial distribution in the metropolitan context.

\section{SPATIALIZATION OF THE “MARACATUS-NAÇÃO” IN THE METROPOLITAN REGION OF RECIFE - PERNAMBUCO}

A basic definition, but not sufficient for this work, about Macaracatu-Nação is necessary for its aesthetic, visual and formal understanding. Thus, Maracatu-Nação is a royal procession that takes on the streets paying honor to the "Reis e Rainhas" (Kings and Queens) (Photo 1), carrying banners and other insignia which are reminiscent of the Portuguese royalty and religious practices of the population of African origin in Brazil.

There are other characters that were also present in the directorate of the Brotherhoods of the Rosary and the coronations of the Kings of Congo accompany the King and Queen in the procession as "Príncipe e Princesa”, (Princes and Princesses), "Damas da Corte” (Ladies of the Court), "Porta-Estandarte” (Standard-bearer), and "Porta-Pálio” (Umbrella-bearer that holds a Eletronic Magazine: Time - Technical - Territory, V.3, N.1 (2012), 43:77 ISSN: 2177-4366 
big and colorful sombrero). There are also “Caboclos” (Indians), referring to indigenous presence in Maracatus-Nação, and "Damas do Paço" (Ladies of the Palace) who carry a black doll named Calunga (Figures 1 and 2).

In Maracatu-Nation there is also a percussive part (Photo 2) composed mainly of alfaias (kinds of drums), gonguês, snare drum and mineiro, which performs the musical part. There are nations that incorporate other instruments as atabaques and agbês which has created discussion around the traditions among the Maracatus (Figure 3). The music of the Maracatu-Nação has been recognized and has achieved national and international fame, leading to formation of various percussive groups in both the RMR and in several states in Brazil and abroad.

Maracatu-Nation is also known as "Maracatu de Baque Virado" formed only by percussive instruments, differing from the "Maracatu Rural" or "Maracatu de Baque Solto", which is very common in the areas of sugar cane plantation and is formed by an orchestra with brass instruments and carries more indigenous references, both in the dance and its characters as in its religious aspect, focused primarily on Jurema (an indigenous religion present in the states of Pernambuco, Alagoas and Paraiba, which worships the enchanted beings of the forest known as "Masters" and "Caboclos"), while "Maracatu-Nação" has its identity more directed toward African matrix. The following figures show the format of the procession of Maracatus-Nação in different periods. Figure 1 refers to mid-twentieth century and Figure 2 shows a procession today, year 2012. 
Figure 1: Maracatu-Nação Elefante Procession Represented by Guerra-Peixe, between 1949 and 1952

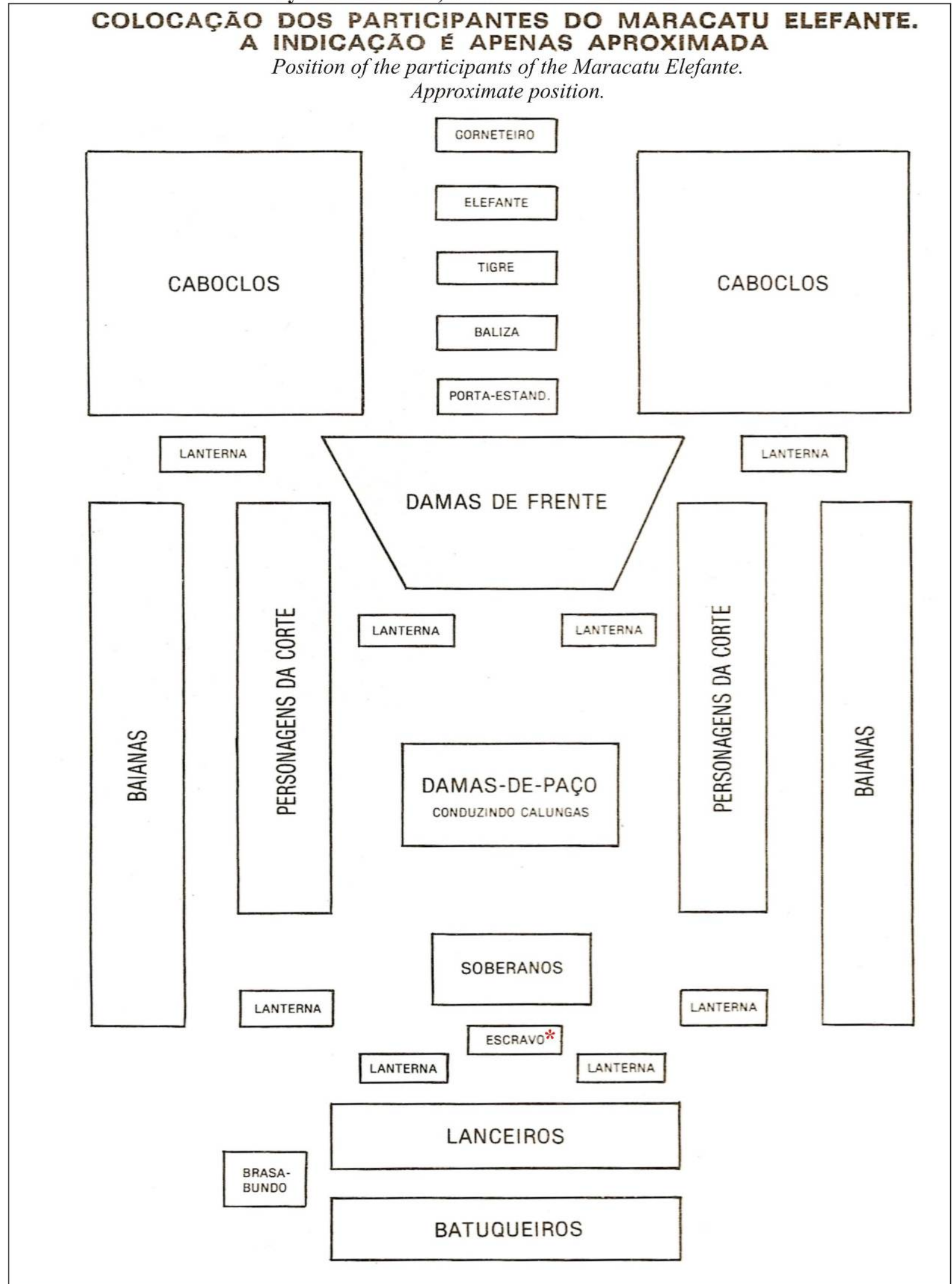

Source: GUERRA-PEIXE, César. Maracatus do Recife, 1981. *The image of the "Slave" in Maracatu-Nação represents the condition that African and African-Brazilians were submitted and referred to the slave system that characterized the society and economy between the 16th and 19th centuries in Brazil. We emphasize that in processions and at parties performed by the Brotherhoods of the Rosary in homage to the Kings and Queens of the Congo, enslaved men and women were present, which may have led Maracatus to persist in the representation of the slave still nowadays. Some terms and words (Portuguese - English): Corneteiro - Bugler; Elefante - Elephant; Tigre - Tiger; Damas de Frente - Front Ladies; Soberanos - Sovereigns; Lanternas - Torchs; Lanceiros - Spearmen; Brasabundo - Bodyguard; Batuqueiros - Drummers. 
Figure 2: Representation of Maracatu-Nação Aurora Africana Procession. Jaboatão dos Guararapes, Pernambuco - 2012.

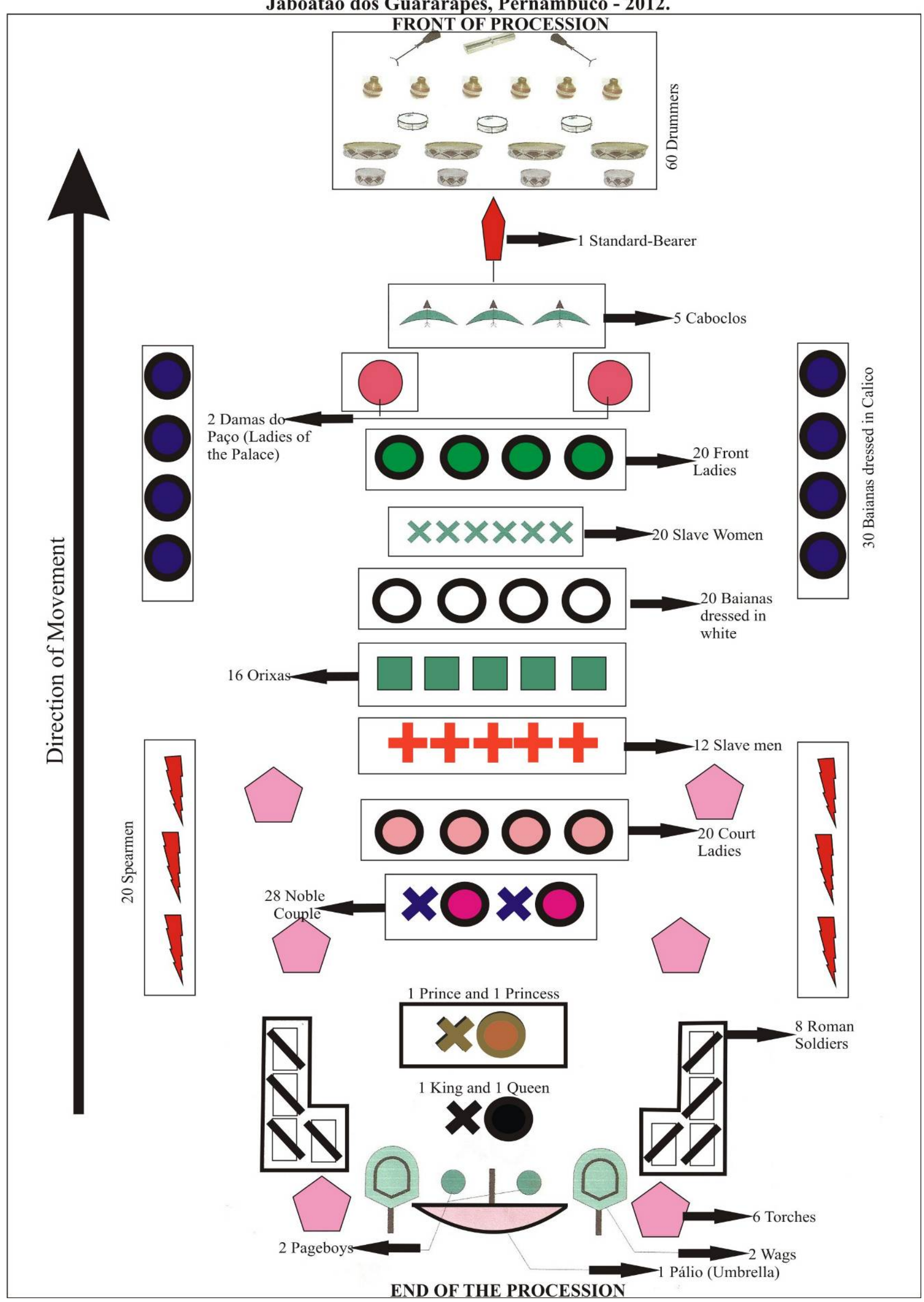


Source: Master Gervásio Monteiro, Maracatu-Nação Aurora Africana, February/2012. Elaborated by Rafal Sanzio A. dos Anjos And Cleison Leite Ferreira.

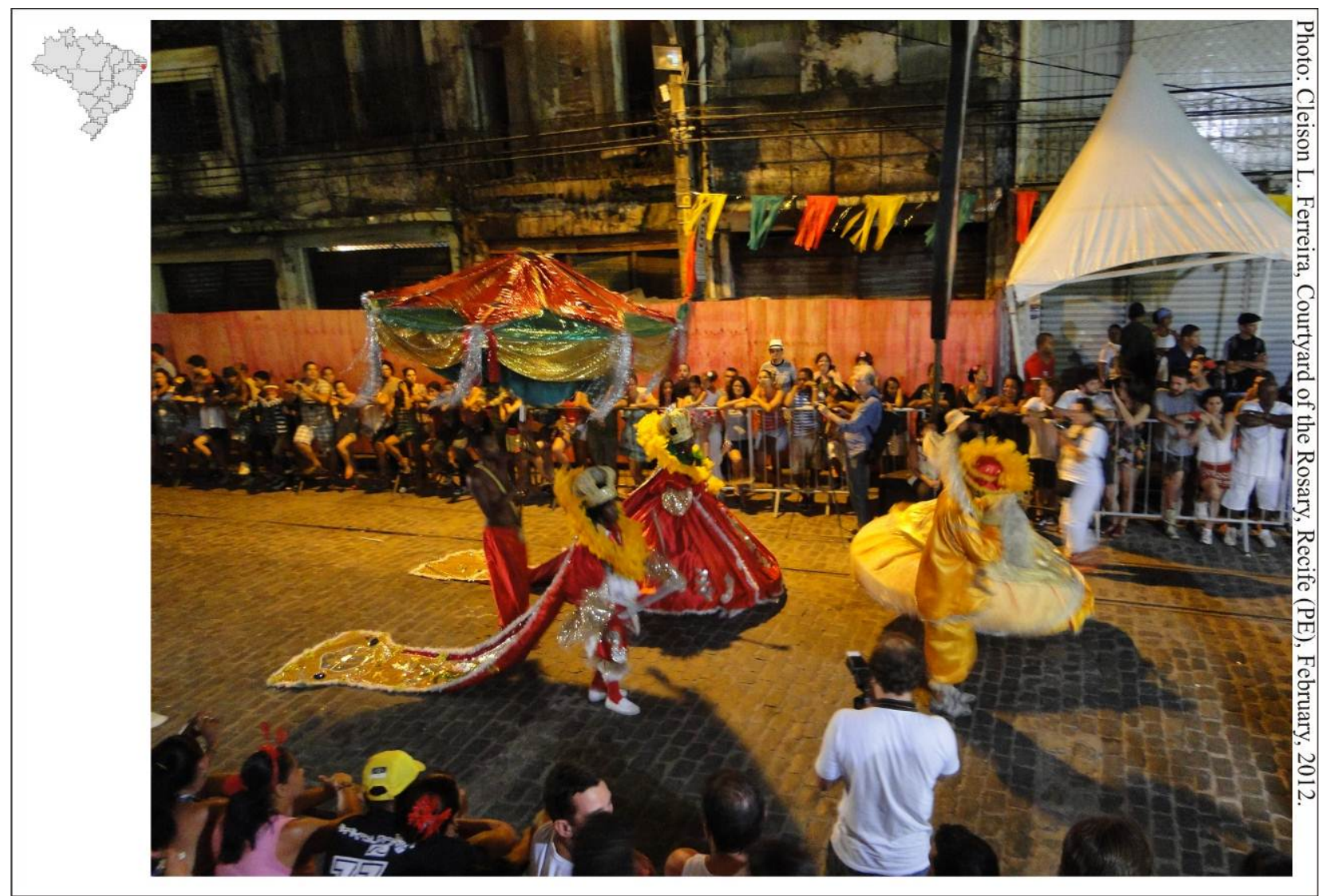

Photo 1: King and Queen of Maracatu-Nação Rosa Vermelha, from Community of Coelhos, Recife - PE.

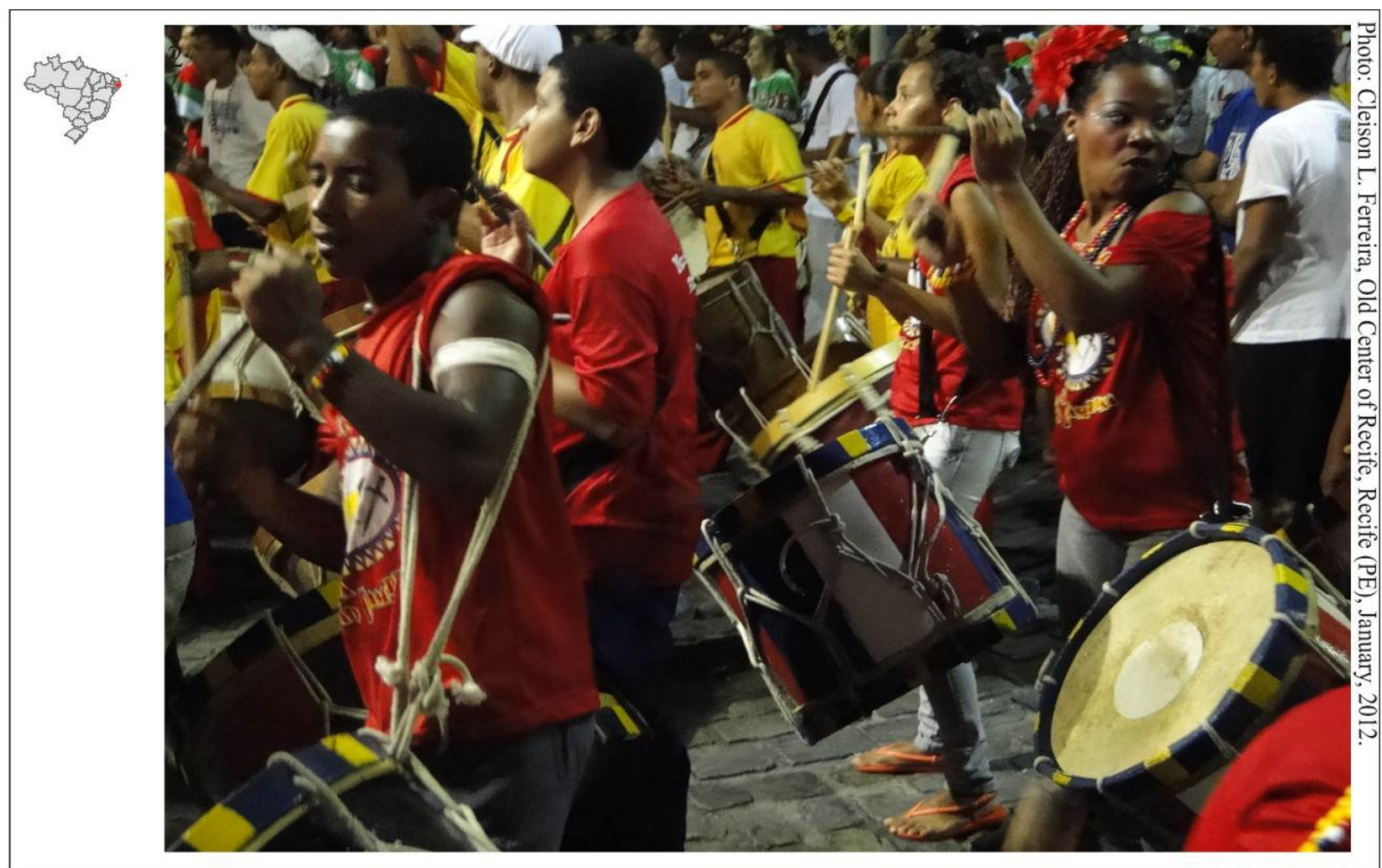

Photo 2: Drummers of Maracatu-Nação Leão da Campina, from Community of Ibura - Recife, PE. Rehearsal of the Official Opening of Recife Carnival-2012. 
Despite the growing number of groups who claim to be Maracatu, they just have been concerned with make the percussive part. They are formed mostly by middle-class youth from different neighborhoods, often university students, trained musicians, curious by the "exotic", which aggregate more for a moment of fun than by an ethnic identity. Even groups that play the characters of the court of a Maracatu and carry its insignias, they do this without the social and religious ties. Their unity does not pass on the ground. These groups are called "stylized" or as the people of the Maracatus-Nação affirm, they are groups of stage.

Thus, we can say that Maracatu-Nação is also defined from a territorial essence, because its identitarian composition is on the ground, in the "terreiro", on the land. Being a MaracatuNação involves community links, affection and shared values among people who compose it. The collective daily life is embedded in what comes to be Maracatu-Nação and an ethos, an ethnocultural reference, is central, and it is what sustains and brings together people who have common stories of ordinary life. In addition to the relationship with the sacred that comes from the Religions of African origin, which also has its essence in the territory. There is the fact that it is called "Nação” (Nation) and not “Grupo” (Group), and is where the boundaries can be drawn among percussive groups, stylized groups, and the Maracatus-Nação.

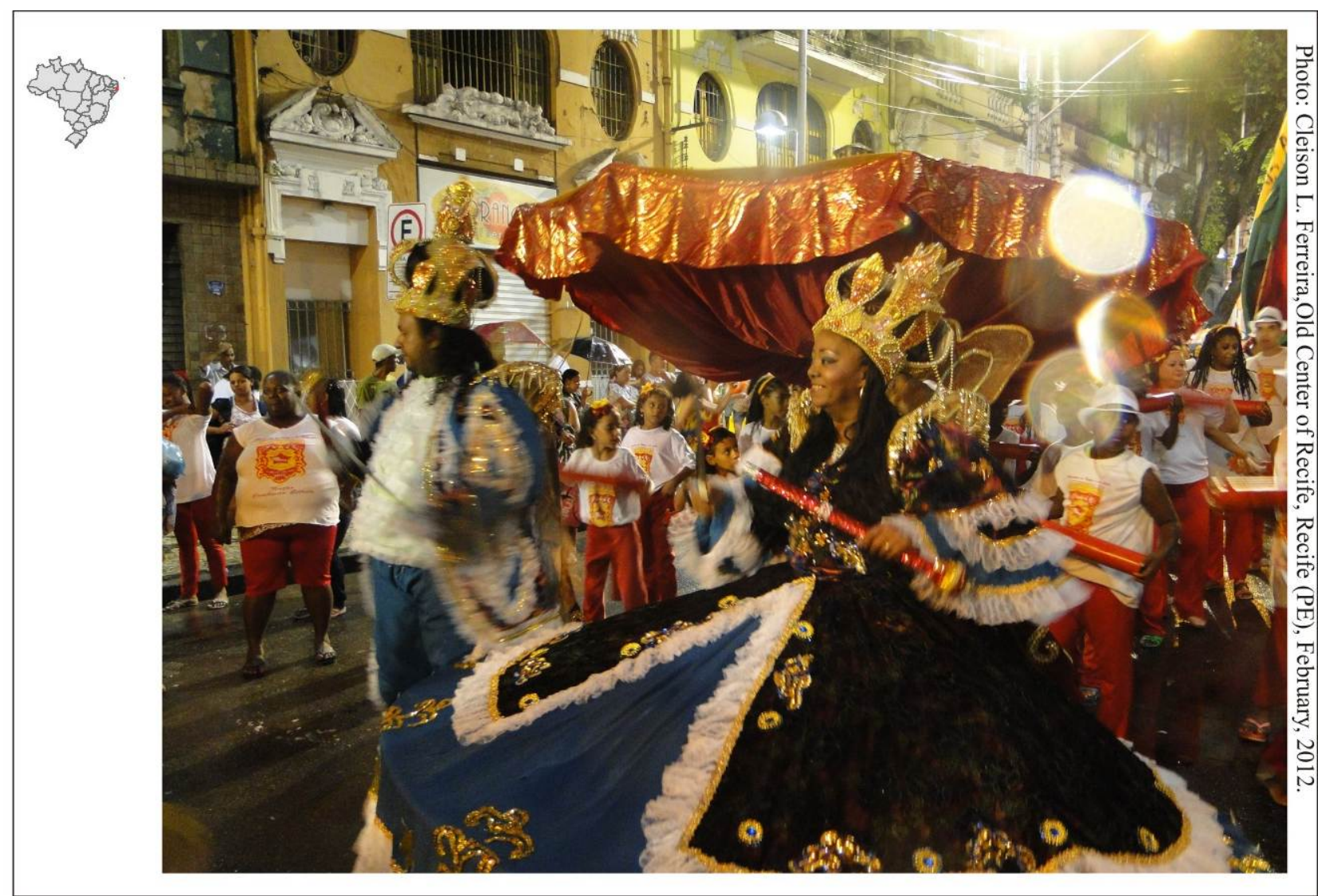

Photo 3: King and Queen of Maracatu-Nação Cambinda Estrela, from the Community of Chão de Estrelas - Recife - PE, followed by drummers in the Official Opening of Recife Carnival-2012. 
Figure 3: The percussive instruments of Maracatu-Nação

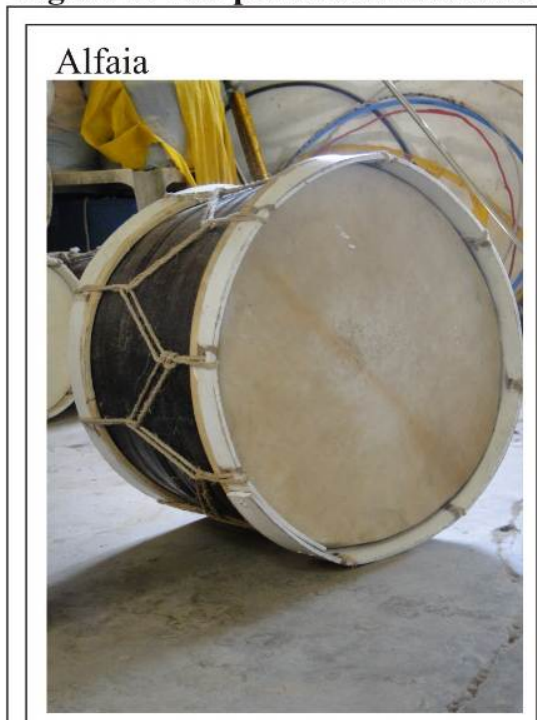

Most Maracatus manufactures and tunes its alfaias in their headquarters, involving a shared knowledge in the family and community between generations. They are made of trunk of a tree called Macaíba, or of plywood. The sound is taken from the part that is covered with calf or goat leather held by a bow tied with sisal rope. It is known also as drum or afaia. Guerra-Peixe (1981) termed it zabumba. But in fieldwork between 2011 and 2012, no nation has used this denomination. Recife, January 2012.

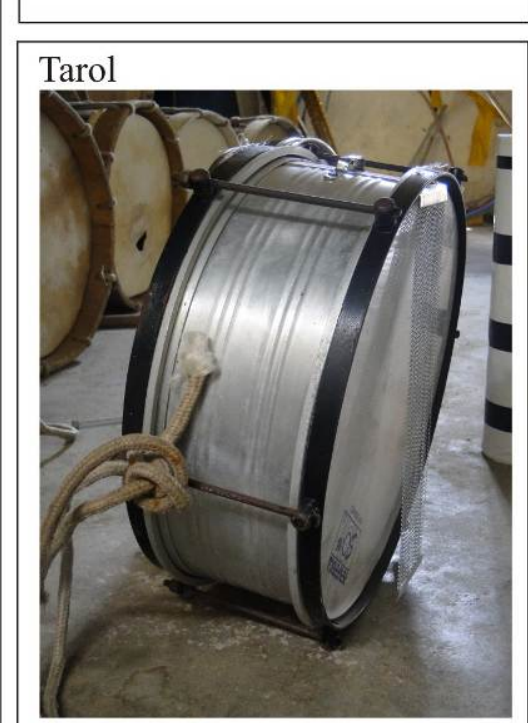

The Tarol, also known as "Caixa», can be med of wood, animal leather and tied with sisal rope. This instruments gives the course of the Maracatu music and fills the spaces left by the alfaias, which have strong and spaced beats. The metal instrument is industrialized, differente of the wooden one that envolves a similar process to the fabrication of alfaias. Recife, January 2012.

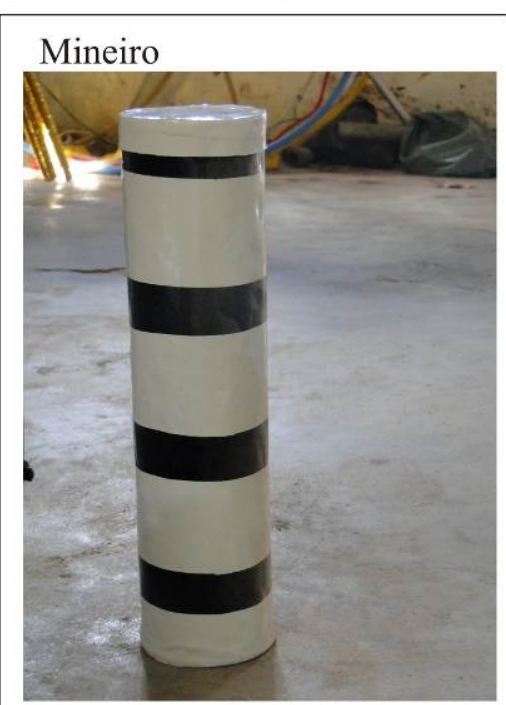

Also called Ganzá, the Mineiro seems to have been gradually being introduced in Maracatu-Nação as the musicologist Guerra-Peixe in his research and fieldwork, between 1949 and 1952, identified that only the Maracatu-Nação Estrela Brilhante used such instrument. Currently all nations use Mineiro accelerating the musical running. Recife, January 2012.

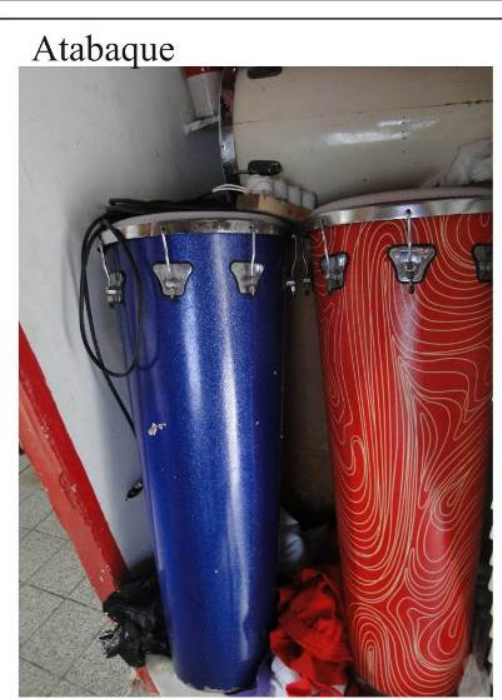

The Atabaque is a new instrument in Maracatu-Nação. Many of the Nations have put them in the percussive part, which has created debate about the traditions. These instruments are used in religious ceremonies in Xango, and as say the Maracatus that claim to be more traditionals, atabaque cannot enter the Maracatu and it must be respected due the sacredness that sorrounds them. Jaboatão dos Guararapes, March 2012.

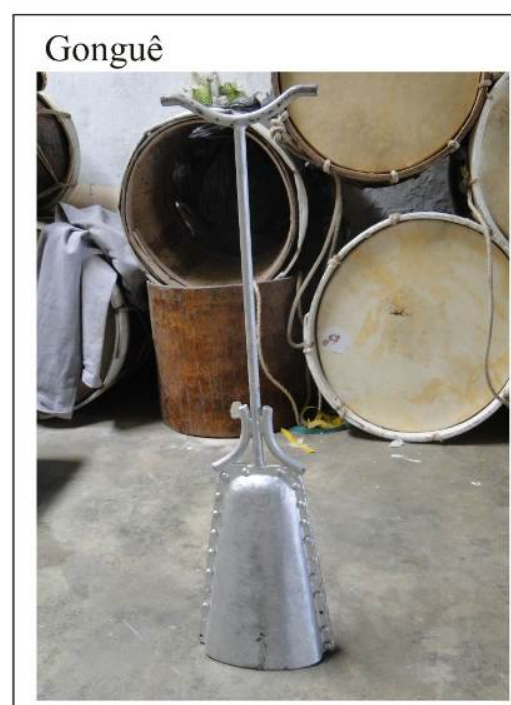

Guerra-Peixe (1981, p. 58) says the name of this instrument came from ngonge, word of Bantu origin. It is similar to another instrument called Agogo, which name came from the Yoruba language. However the gonguê has only one bell and is played in streets events, while the agogo is smaller, has two bells, and is used in rituals in the Xango Terreiros. This instrument comes in front of percussion to make way. Accordin to an informant, member of Maracatu-Nação Leão Coroado, from Olinda, as well as agogo, this instrument «comes asking $\mathrm{AGO}$ », that in Yoruba «means licence, permission to enter». Recife, January 2012.

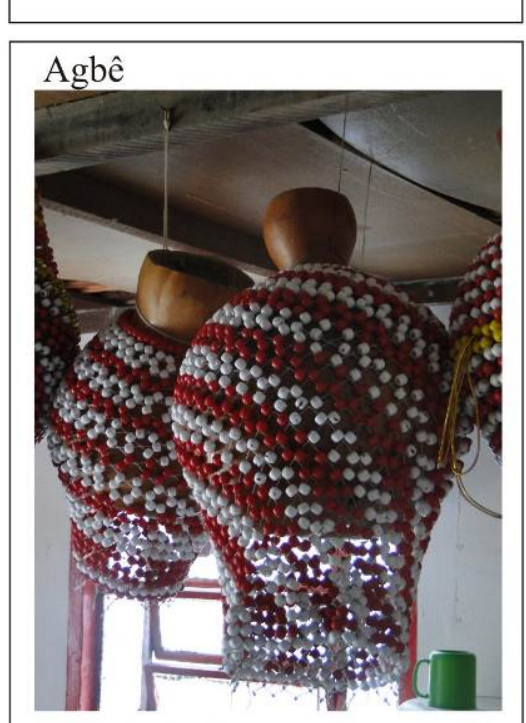

The Agbe is also a new instrument in Maracatu-Nação. It is of gêge-nagô tradition and has a similar function to the Mineiro. In addition to accelerating the music it fills the gaps left by other instruments. Its incorporation into the Maracatu is due to the searching of African references, an identitarian affirmation, and political forces in the culture. Jaboatão dos Guararapes, March 2012

Sources: GUERRA-PEIXE, César. Maracatus do Recife, 1981. Interviews with Masters of Maracatus-Nação between January and March, 2012. The quantitiy of instruments varies among the Nations, and the alfaias are the most numerous. In 2012 was identified a nation composed of 111 instruments: 65 alfaias, 2 mineiros, 6 gonguês, 18 tarois (6 of metal and 12 wooden) and 20 agbês. Each percussive part has a Master of percussion that conducts and organizes the percussion. 
In 2006, there were twenty-three Nations of Maracatu in Pernambuco (Maps 1 and 2), in the cities of Recife, Olinda, Jaboatão Guararapes, Igarassu and Cabo de Santo Agostinho. In 2012, the number of nations rose to twenty-seven (Table 1), having their headquarters located in poor communities of Recife, Olinda, Jaboatão dos Guararapes and Igarassu (Maps 3 and 4). At first Maracatus-Nação headquartes were located in the central areas of the cities, or in their proximities, where the African population in Recife that lived in the urban space played place with the local elite. Also there were located in those places the main areas of social and symbolic spaces of the African population, as the churches where they performed their devotions, the coronations and the festivities of Kings and Queens, and their Xango Terreiros ${ }^{3}$.

Several situations were responsible for the displacement of population to distant areas of the center or areas of little interest to the local elites such as canals, wetlands, the tops of the hills (Map 6). Among the actions that led people to distance themselves from their symbolic spaces moving toward a new urban context stand out, associated and subsequent specially in the years 30 and 50, the policies of sanitization; the policies of modernization of the urban centers and its consequent real estate investment to building standards that met the middle class, industrialists and merchants, and the constant persecution of the religions and cultural aspects of the population of African origin.

But the people did not abandon their practices, because while they helped to build new neighborhoods, they built on them sociability around the culture and religion, bringing their worship to African divinities (the Orixas), and their Maracatus-Nação, printing in the territory their ethnic and cultural references and defining territoriality. In addition, the city of Recife and its metropolitan region constituted the territory of Maracatu-Nação and therefore embrace the identity constructed by the cultural practices of the African population.

\footnotetext{
3 In Pernambuco the Religion of Candomble is known as Xango. This Matrix African Religion in Brazil is not a homogeneous whole. It is the result of historical processes and differentes contexts through which africanBrazilian population passed, which had in each place of the country to articulate through various ways such as survival and maintenance of their practices. Candomblé is also characterized by different forms of worship of the Orixas, being recognized by nations. In Bahia, for example, the Candomble Terreiros are predominantly identified as Ketu Nation. In Pernambuco, the religion of Xango has much of its Terreiros identified as Nago Nation. In Maranhao, Piaui, Para and Amazonas predominates Tambor de Mina, a religion of Jeje-Nago Nation.
} 
TABLE 1 - MARACATUS-NAÇÃO OF PERNAMBUCO - 2012

\begin{tabular}{|c|c|c|c|}
\hline $\begin{array}{c}\text { NAME OF THE } \\
\text { MARACATU }\end{array}$ & $\begin{array}{c}\text { YEAR OR } \\
\text { FOUNDATION }\end{array}$ & $\begin{array}{l}\text { NEIGHBORHOOD OF } \\
\text { HEADQUARTERS }\end{array}$ & $\begin{array}{l}\text { GEOGRAPHIC } \\
\text { CORDINATES }\end{array}$ \\
\hline Nação Elefante & 1800 & $\begin{array}{c}\text { Bomba do Hemetério } \\
\text { Recife }\end{array}$ & $\begin{array}{l}8^{\circ} 1 \text { '14.48" South } \\
34^{\circ} 54^{\prime} 3.90^{\prime \prime} \text { West }\end{array}$ \\
\hline $\begin{array}{l}\text { Nação Estrela Brilhante de } \\
\text { Igarassu }\end{array}$ & 1824 & $\begin{array}{c}\text { Sítio Histórico de } \\
\text { Igarassu }\end{array}$ & $\begin{array}{l}7^{\circ} 48 ' 38.02^{\prime \prime ~ S} \\
34^{\circ} 55^{\prime} 25.26^{\prime \prime} \mathrm{W}\end{array}$ \\
\hline Nação Leão Coroado & 1863 & $\begin{array}{c}\text { Águas Compridas } \\
\text { Olinda }\end{array}$ & $\begin{array}{l}7^{\circ} 59 \text { '36.93" S } \\
34^{\circ} 53 \text { '35.16" W }\end{array}$ \\
\hline $\begin{array}{l}\text { Nação Estrela Brilhante de } \\
\text { Recife }\end{array}$ & 1906 & $\begin{array}{l}\text { Alto José do Pinho } \\
\text { Recife }\end{array}$ & $\begin{array}{l}8^{\circ} 1 ' 23.39 " \mathrm{~S} \\
34^{\circ} 54^{\prime} 11.98^{\prime \prime} \mathrm{W}\end{array}$ \\
\hline Nação Porto Rico & 1916 & $\begin{array}{c}\text { Pina } \\
\text { Recife }\end{array}$ & $\begin{array}{l}8^{\circ} 5 \text { '38.23"S } \\
34^{\circ} 53^{\prime} 18.33^{\prime \prime} \mathrm{W}\end{array}$ \\
\hline Nação Almirante do Forte & 1931 & $\begin{array}{l}\text { Bonji } \\
\text { Recife }\end{array}$ & $\begin{array}{l}8^{\circ} 3^{\prime} 48.26 " \mathrm{~S} \\
34^{\circ} 55^{\prime} 6.48^{\prime \prime} \mathrm{W}\end{array}$ \\
\hline Nação Cambinda Estrela & 1935 & $\begin{array}{l}\text { Chão de Estrelas } \\
\text { Recife }\end{array}$ & $\begin{array}{l}8^{\circ} 1 ' 11.53^{\prime \prime S} \\
34^{\circ} 53^{\prime} 0.35^{\prime \prime} \mathrm{W}\end{array}$ \\
\hline Nação Cambinda Africana & 1964 & $\begin{array}{c}\text { Campina do Barreto } \\
\text { Recife }\end{array}$ & $\begin{array}{l}8^{\circ} 0^{\prime} 53.74 " \mathrm{~S} \\
34^{\circ} 52^{\prime} 48.71^{\prime \prime} \mathrm{W}\end{array}$ \\
\hline Nação Tigre & 1975 & $\begin{array}{l}\text { Peixinhos } \\
\text { Olinda }\end{array}$ & $\begin{array}{l}8^{\circ} 0^{\prime} 29.94 " \mathrm{~S} \\
34^{\circ} 52 ' 53.77^{\prime \prime W}\end{array}$ \\
\hline Nação Encanto do Pina & 1980 & $\begin{array}{c}\text { Pina } \\
\text { Recife }\end{array}$ & $\begin{array}{l}8^{\circ} 5 \text { '31.32"S } \\
34^{\circ} 53 \text { '23.99"W }\end{array}$ \\
\hline Nação Linda Flor & 1984 & $\begin{array}{l}\text { Macaxeira } \\
\text { Recife }\end{array}$ & $\begin{array}{l}8^{\circ} 0^{\prime} 58.80 " \mathrm{~S} \\
34^{\circ} 55^{\prime} 49.22^{\prime \prime} \mathrm{W}\end{array}$ \\
\hline Nação Sol Nascente & 1986 & $\begin{array}{l}\text { Água Fria } \\
\text { Recife }\end{array}$ & $\begin{array}{l}8^{\circ} 1 \text { 1'20.09"S } \\
34^{\circ} 53^{\prime} 43.41^{\prime \prime} \mathrm{W}\end{array}$ \\
\hline Nação Tupinambá & 1989 & $\begin{array}{l}\text { Vasco da Gama } \\
\text { Recife }\end{array}$ & $\begin{array}{l}8^{\circ} 1 \text { '11.23"S } \\
34^{\circ} 55^{\prime} 21.16^{\prime \prime} \mathrm{W}\end{array}$ \\
\hline Nação Gato Preto & 1989 & $\begin{array}{c}\text { Alto dos Coqueiros } \\
\text { Recife }\end{array}$ & $\begin{array}{l}8^{\circ} 0 \text { '34.26"S } \\
34^{\circ} 54^{\prime} 1.51^{\prime \prime} \mathrm{W}\end{array}$ \\
\hline Nação Estrela Dalva & 1990 & $\begin{array}{c}\text { Joana Bezerra } \\
\text { Recife }\end{array}$ & $\begin{array}{l}8^{\circ} 4^{\prime} 24.28^{\prime \prime S} \\
34^{\circ} 53^{\prime} 41.39^{\prime \prime} \mathrm{W}\end{array}$ \\
\hline Nação Leão da Campina & 1997 & $\begin{array}{c}\text { Ibura } \\
\text { Recife } \\
\end{array}$ & $\begin{array}{l}8^{\circ} 7^{\prime} 50.17 " \mathrm{~S} \\
34^{\circ} 56^{\prime} 54.91^{\prime \prime} \mathrm{W}\end{array}$ \\
\hline Nação de Luanda & 1997 & $\begin{array}{c}\text { Cidade Tabajara } \\
\text { Olinda }\end{array}$ & $\begin{array}{l}7^{\circ} 58^{\prime} 48.17 " \mathrm{~S} \\
34^{\circ} 52^{\prime} 17.30^{\prime \prime W}\end{array}$ \\
\hline Nação Axé da Lua & 1998 & $\begin{array}{l}\text { Peixinhos } \\
\text { Olinda }\end{array}$ & $\begin{array}{l}8^{\circ} 0^{\prime} 59.94 " \mathrm{~S} \\
34^{\circ} 52 \text { '21.95"W }\end{array}$ \\
\hline Nação Raízes de Pai Adão & 1998 & $\begin{array}{l}\text { Água Fria } \\
\text { Recife }\end{array}$ & $\begin{array}{l}8^{\circ} 11^{\prime} 18.86 " \mathrm{~S} \\
34^{\circ} 53^{\prime} 41.65^{\prime \prime} \mathrm{W}\end{array}$ \\
\hline Nação Encanto da Alegria & 1998 & $\begin{array}{l}\text { Mangabeira } \\
\text { Recife }\end{array}$ & $\begin{array}{l}8^{\circ} 1 ' 28.47 " \mathrm{~S} \\
34^{\circ} 54 ' 15.14^{\prime \prime} \mathrm{W}\end{array}$ \\
\hline Nação Encanto do Dendê & 1998 & $\begin{array}{c}\text { Guabiraba } \\
\text { Recife }\end{array}$ & $\begin{array}{l}7^{\circ} 59^{\prime} 6.47^{\prime \prime S} \\
34^{\circ} 55^{\prime} 52.92^{\prime \prime W}\end{array}$ \\
\hline Nação Rosa Vermelha & 2001 & $\begin{array}{c}\text { Bairro dos Coelhos } \\
\text { Recife }\end{array}$ & $\begin{array}{l}8^{\circ} 4^{\prime 2} 2.23 " \mathrm{~S} \\
34^{\circ} 53^{\prime} 14.01^{\prime \prime} \mathrm{W}\end{array}$ \\
\hline Nação Aurora Africana & 2001 & $\begin{array}{c}\text { Vila Rica } \\
\text { Jaboatão dos Guararapes }\end{array}$ & $\begin{array}{l}8^{\circ} 7 ' 8.72 " \mathrm{~S} \\
35^{\circ} 1 ' 38.40^{\prime \prime} \mathrm{W}\end{array}$ \\
\hline Nação Oxum Mirim & 2002 & $\begin{array}{l}\text { Afogados } \\
\text { Recife }\end{array}$ & $\begin{array}{l}8^{\circ} 3^{\prime} 53.22 " \mathrm{~S} \\
34^{\circ} 54^{\prime} 40.54^{\prime \prime} \mathrm{W}\end{array}$ \\
\hline Nação Estrela de Olinda & 2004 & $\begin{array}{c}\text { Guadalupe } \\
\text { Olinda }\end{array}$ & $\begin{array}{l}8^{\circ} 00^{\prime} 27.6 " \mathrm{~S} \\
34^{\circ} 51 ' 21.2^{\prime \prime} \mathrm{W}\end{array}$ \\
\hline $\begin{array}{l}\text { Nação Lira do Morro da } \\
\text { Conceição }\end{array}$ & 2010 & $\begin{array}{l}\text { Morro da Conceição } \\
\text { Recife }\end{array}$ & $\begin{array}{l}8^{\circ} 1 ' 13.9^{\prime \prime S} \\
34^{\circ} 54^{\prime} 44.5^{\prime \prime W}\end{array}$ \\
\hline
\end{tabular}

Source: Association of the Maracatus-Nação of Penambuco, January 2012. Elaboration: Cleison Leite Ferreira and Rafael Sanzio A. dos Anjos. Technical Support: Center of Applied Cartography and Geografic Information, University of Brasilia - CIGA/UnB. 


\section{MAP 1 - OCCURRENCES OF MARACATUS-NAÇÃO \\ IN BRAZIL - 2006}

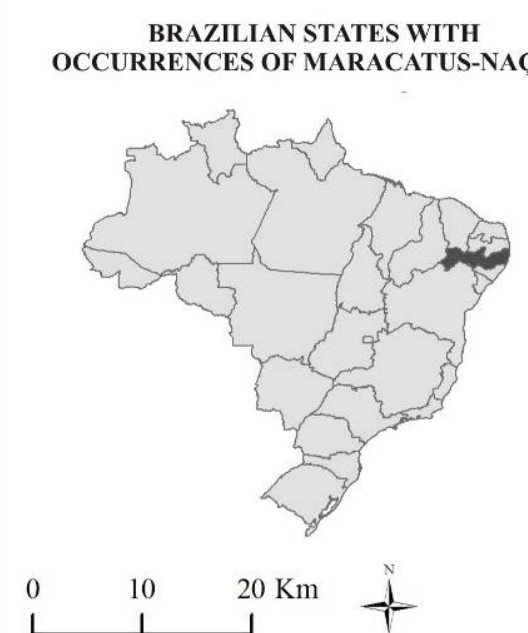

PERNAMBUCO MUNICIPALITIES WITH OCCURRENCES OF MARACATUS-NAÇÃO - 2006
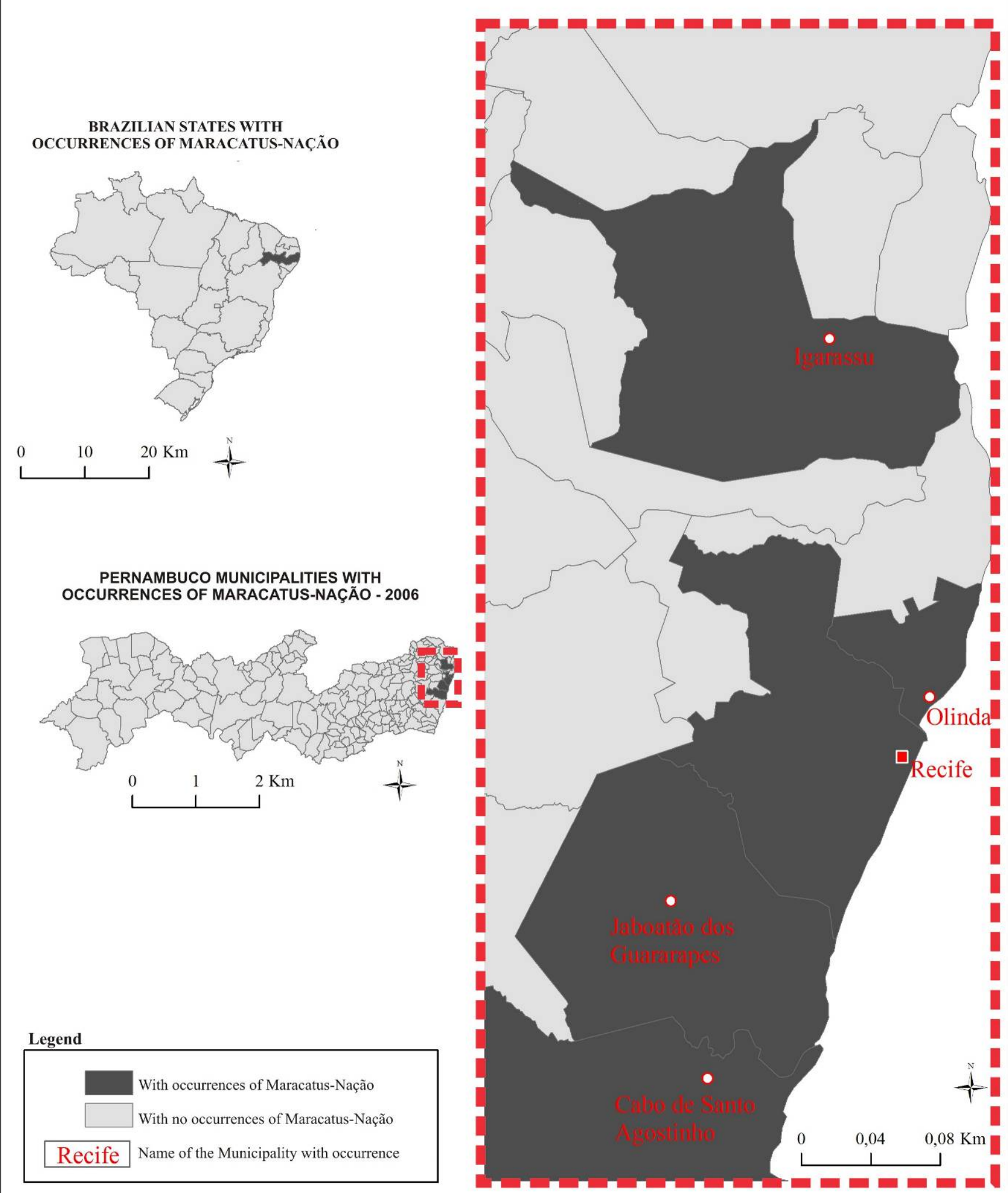

Cartographic Base IBGE/2000. Source: ANJOS, Rafael Sanzio Araújo dos. Alguns Registros Espaciais dos Maracatus - Pernambuco - Brasil Project African-Brazilian Geography - Center of Applied Cartography and Geographic Information, University of Brasilia, CIGA/UnB - 2006. 


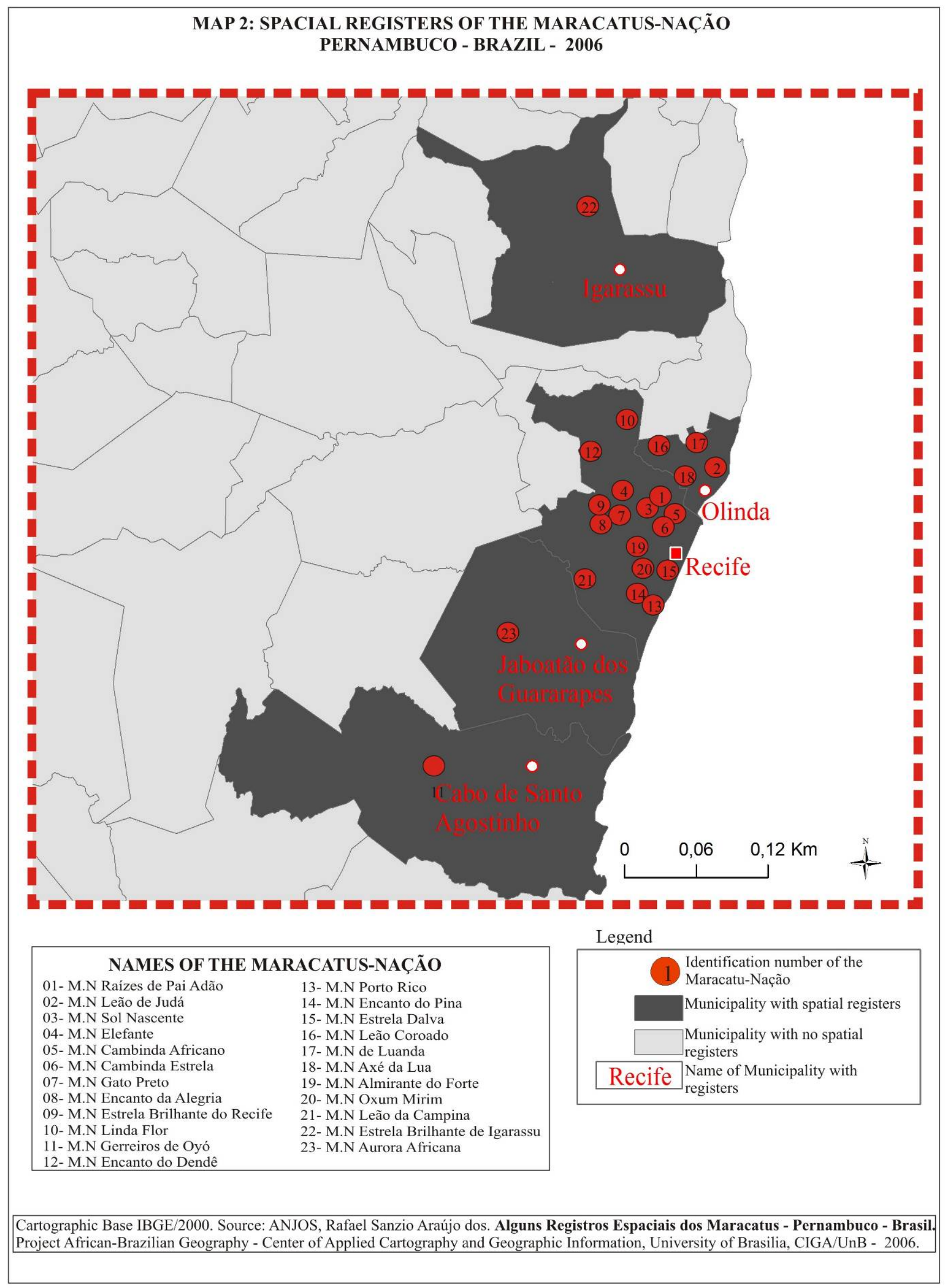

Eletronic Magazine: Time - Technical - Territory, V.3, N.1 (2012), 43:77 ISSN: 2177-4366 


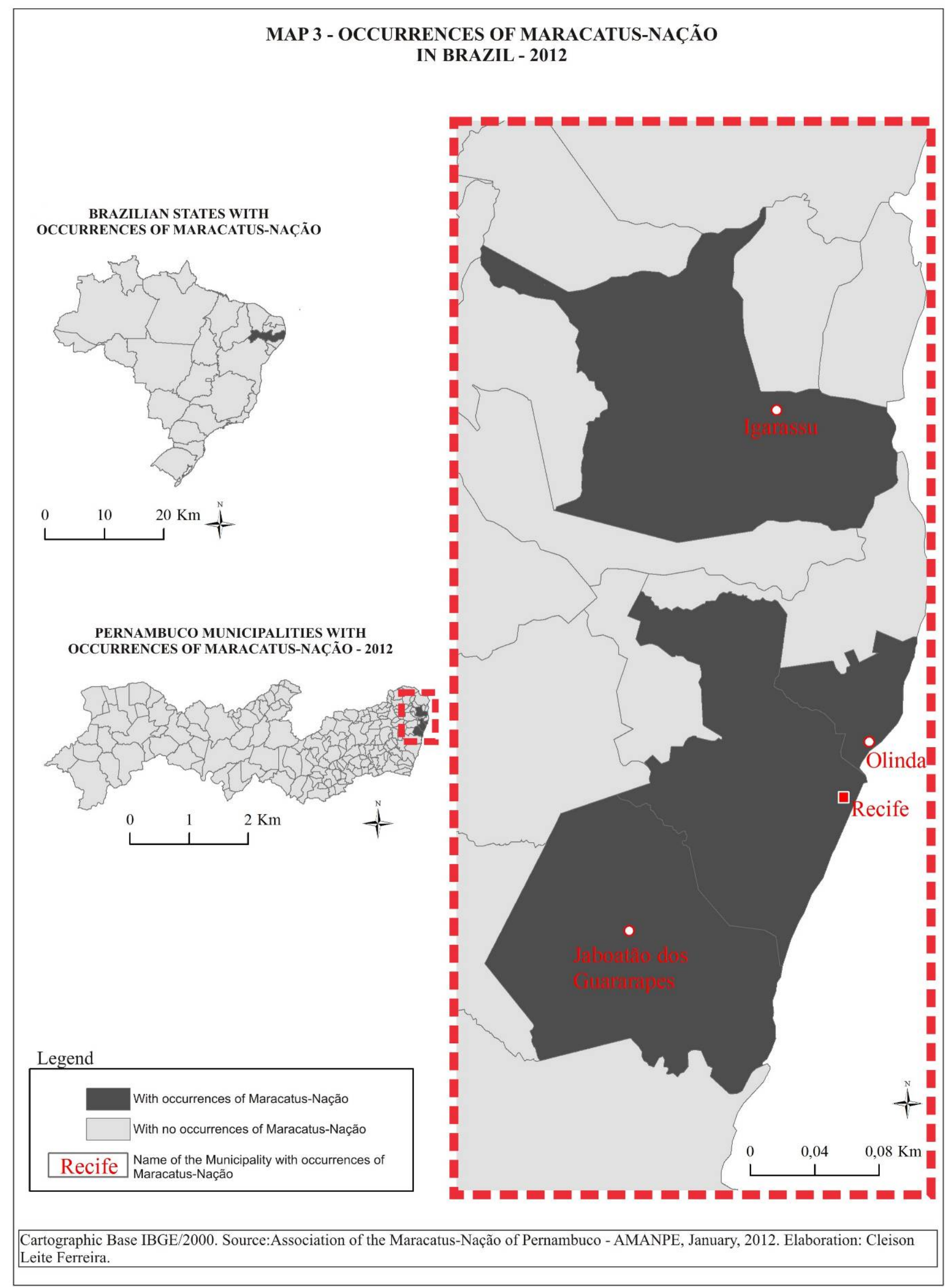




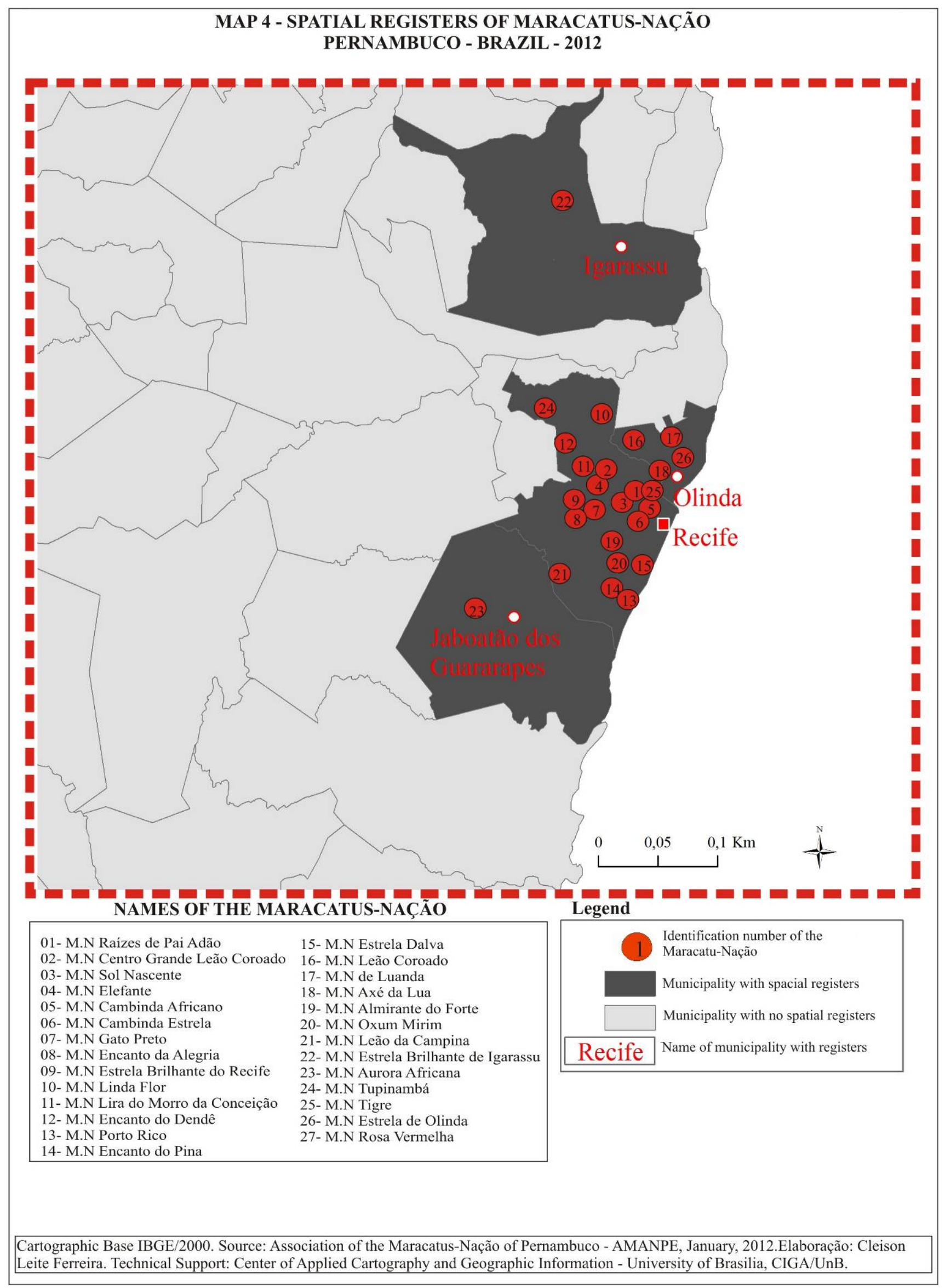

Eletronic Magazine: Time - Technical - Territory, V.3, N.1 (2012), 43:77 ISSN: 2177-4366 


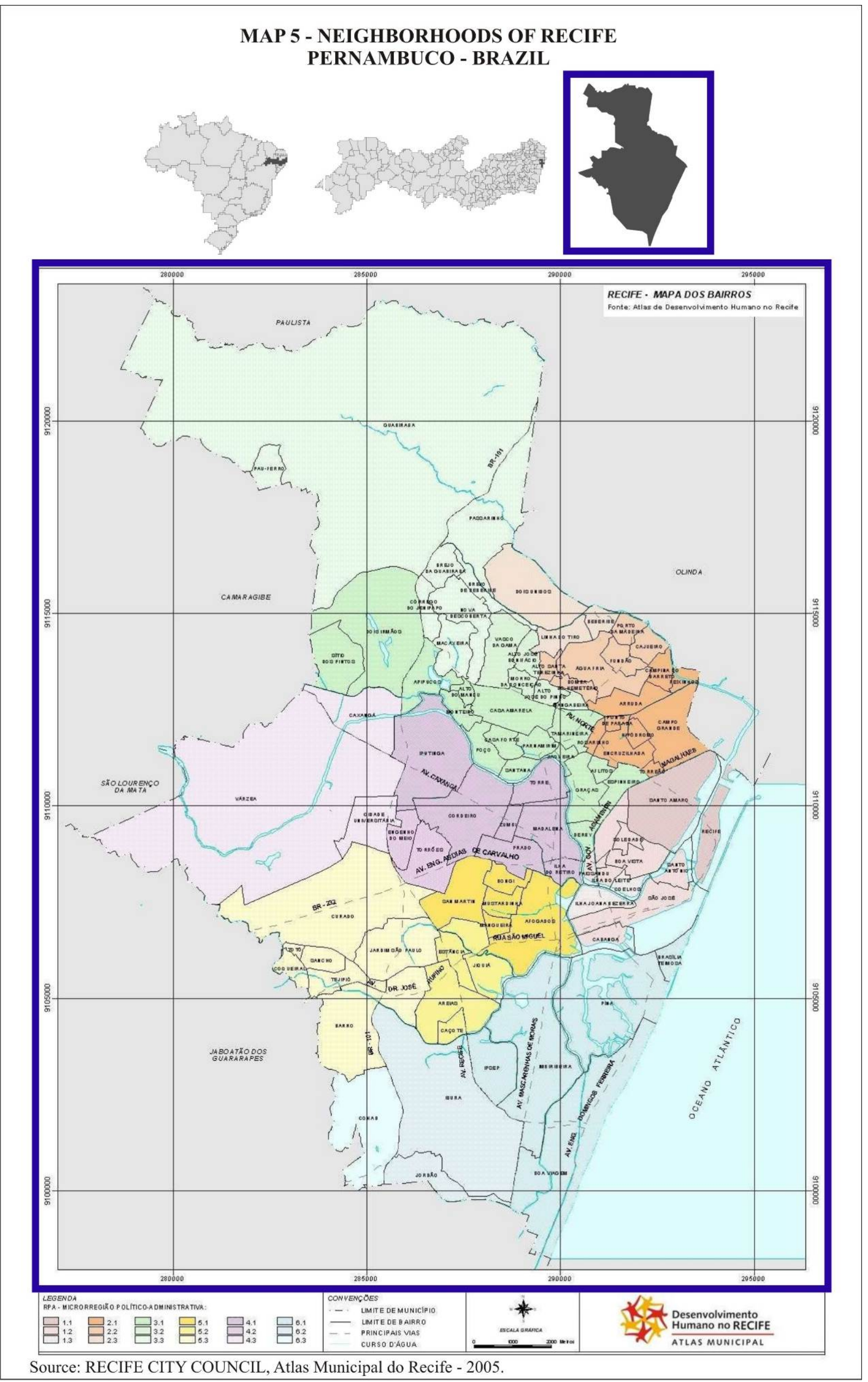




\section{MAP 6 - MARACATUS-NAÇÃO OF NORTH ZONE OF RECIFE AND PEIXINHOS COMMUNITY IN} OLINDA - PERNAMBUCO - 2012
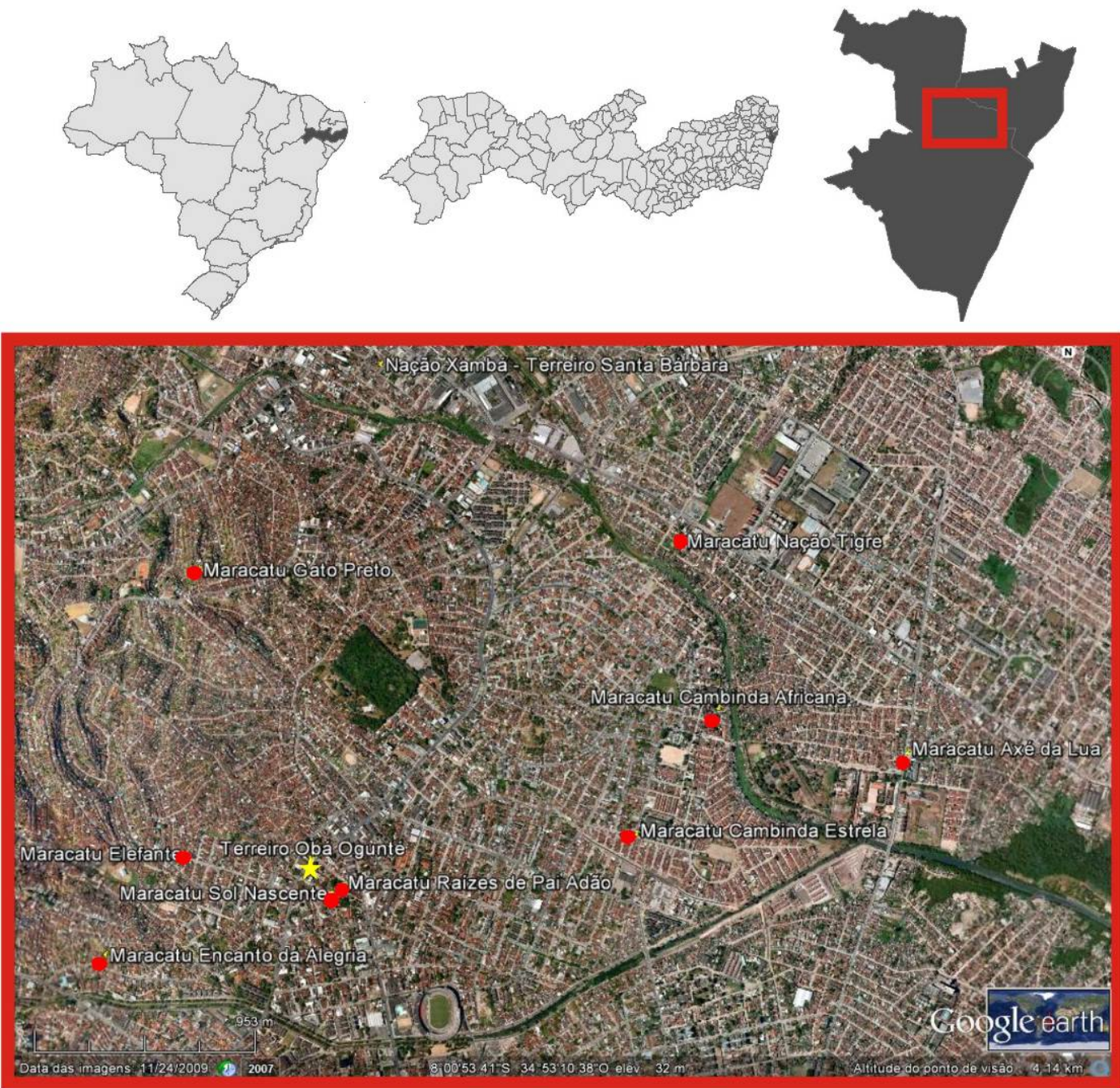

Legend

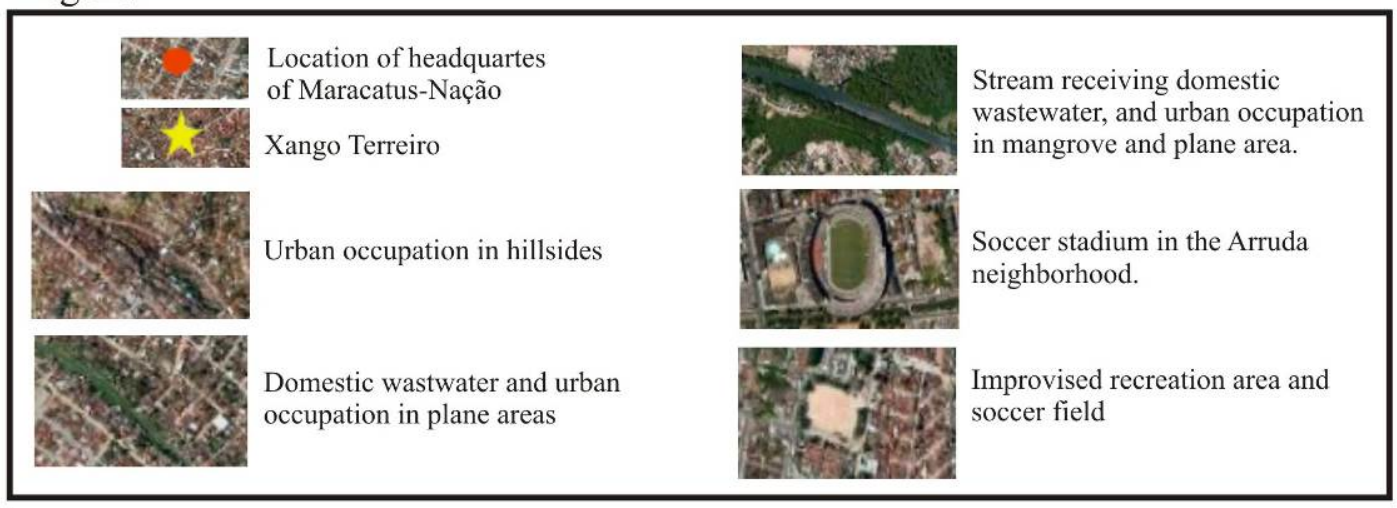

Cartographic Base - IBGE/2000. Image: Google Earth, 11/16/2011. Source: Center of African-Brazilian Culture Recife City Council, Janeiry, 2012. Elaborated by: Cleison Leite Ferreira. Technical Support: Center of Applied Cartography and Geographic Information- University of Brasilia - CIGA/UnB. 
The Maps 1 and 3 show the Maracatu-Nação as an African-Brazilian phenomenon present only in the Brazilian state of Pernambuco, and within this state the occurrences are in cities of the Metropolitan Region of Recife. The primary issue that allows us to affirm the Maracatu-Nação to be associated with Recife is a number of factors involving the historical formation, composition and ethnic references, religions, symbolism, and community links - social practices that endow the space of sentimental values of belonging and ownership, which constitutes the formation of territories.

There is a concentration of headquarters of Maracatus-Nação in an area of the Metropolitan Region of Recife, which is the North Zone of Recife and part of the West of Olinda, seen on Map 4 and in detail on Map 6. The headquarters are located in communities in the districts of Água Fria, Campina do Barreto, Bomba do Hemetério, Alto Santa Terezinha, Mangabeira, and Peixinhos (Map 5). In this spatial area is located largely deterritorialized population of the downtown area of Recife, especially the population of African origin, for reasons already mentioned briefly. In this area also focus many Xango, Umbanda, and Jurema Terreiros as the "Terreiro Nago Oba Ogunté" (known around town as "The Site of Father Adão") in the district of Agua Fria, and the “Terreiro Xamba Santa Barbara”, in the community of "Portão do Gelo”, in Olinda. Thus, this area is permeated with values and feelings shared by a community that has common features both with regard to socioeconomic status in relation to identity aspects. An ethos unites and fills that location within a larger space, differentiating it from the whole, not as a fragment of space, but a rearrangement or a new territorial base where the population neglected by public policies and secularly pursued re-territorialized and established a safe place for their cultural and religious practices.

Corrêa (2006, p. 252) points out that the act of deterritorialize is understood "as the loss of the appropriate and lived territory by reason of contradictions derived from different processes able to rid the territory" and for the same author, re-territoriality or new territoriality means the creation of new territories through or partial reconstruction of the old territories or in other places, of a new territory that contains some of the features of the old territory (CORREA, 2006).

The forced displacement promoted by the State and a demand for housing for the poorest populations, especially those with African references, made the city of Recife ever grew mainly towards the North Zone where there is a physiographic area defined by flat field and hills. And where is concentrated the largest population density, with a total of 205,986 inhabitants occupying an area of $14.89 \mathrm{~km}^{2}$. There was also the occupation of other areas distant from the center that promoted the unification of deterritorialized populations around aspects of identity and social objectives, largely those relating to ethnic identity of African origin, with the MaracatusNação as the main occupation strategy, definition and identification of the territory.

Eletronic Magazine: Time - Technical - Territory, V.3, N.1 (2012), 43:77 ISSN: 2177-4366 
In Map 6 is possible to observe with more detail the characteristics of the area where there is a greater concentration of Maracatu-Nação. Besides being a largely rugged terrain with hills area, the population lives with the scarcity of water, poor sanitation, little pavement streets, a few green areas and many channels through which the sanitary sewage from residences toward watercourses.

Each headquarters represents the physical space where the objects of the Maracatus-Nação are stored, where they made clothes, musical instruments are produced and is the reference point of the Nation. It is also a space for consecration and religious experience. It is from whence radiate the actions and mobilization that reflect the cultural space and it is for that target the search for identity and social ties, performing a cycle powered internally and externally. And in this movement is that they are defined territorialities as discussed below.

\section{TERRITORIALITIES IN THE HEADQUARTES OF MARACATUS-NAÇÃO IN RECIFE - PERNAMBUCO}

The headquarters of Maracatus-Nação are inserted, as already described, in a metropolitan context of social exclusion. Despite the social ills that accompany the "maracatuzeiros" (people who do Maracatu), these are not intimidated and are articulated in the face of little visibility that they have as residents of the city, creating strategies that lead not only to reveal in their daily activities as in the city center and other public spaces.

In the following section, we present some of the practices of the Maracatus-Nação that were built slowly and have repercussions throughout the Metropolitan Region of Recife, establishing an identity of African origin to the whole, despite the "denial" and little recognition from the elite of Pernambuco. We believe these practices are territorialities because they are material and symbolic expressions which guarantee the permanence of ownership of the territory (Corrêa, 2006, 252).

\subsection{Daily and community ties: territorialities in the neighborhoods of Recife - PE}

The headquarters of the Maracatus-Nação have functioned as meeting place and everyday sociability of children, youth and elderly as well as sharing of cultural values and symbolic issues around ethnic aspects, articulated themselves around improvements to the neighborhood, leisure time and communication.

Daily, especially in the days preceding and following the carnival, there is a great movement around the headquarters. There are people who go to manufacture the clothes, as embroiderers and seamstresses; to fabricate or tune musical instruments; to manufacture the props; to bring food to those who are working day and night; to talk, observe, play, and have fun. The movement is visible in and near the headquarters, not only active participants of the Maracatus-Nação, but also the entire neighborhood. There are even moments of essays that take an entire street, mobilize the community and create a time-space for exchanging experiences, of sharing the hardships, and appreciation of 
their cultural values. On these occasions, the headquarters of the Maracatus-Nação, in the context of the neighborhood, are places of community references, and are present in the collective imaginary (Figure 4).

Each Maracatu-Nação, even having the headquarters as its reference point tied to a neighborhood also articulates spatially beyond its immediate area, which horizontally may refer to the notions of extension and breadth. The limits of performance can generate spaces of intersection between more than one Maracatu and spaces of exclusivity. This fact is explained by the participation of drummers, members of the court, people who make clothes and musical instruments, so on, not only from the neighborhood where the headquarters is located, as well as other neighborhoods or other municipalities. Or, a Maracatu-Nação does not extend to other neighborhood because in it already exists the presence of some other Nation.

Thus, there are movements and routes around the headquarters of Maracatu-Nação. As exposes Rosendahl (2007), there is a territoriality based on relationships that are maintained with the place of reference, headquarters (fixed), and the movements made by people on the routes that constitute the territory. 
Figure 4: The Maracatu-Nação Cambinda Estrela, from Community of Chão de Estrelas, Recife - PE

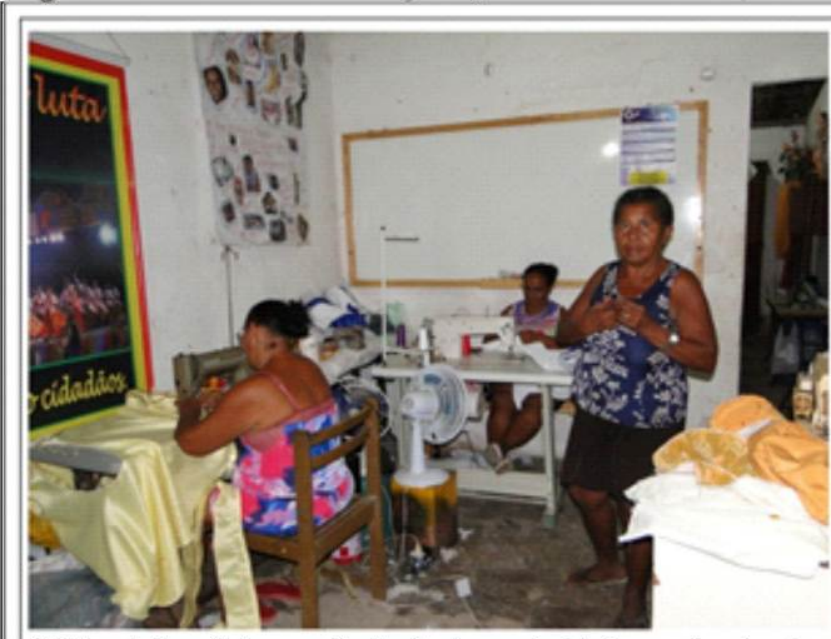

Making clothes of Maracatu-Nação. Sewing, embroidering, cutting, drawing, are actions that go beyond te act of producing. It is a moment that involves daily practive and knowlege through sociability, community ties, affective links and territorial and community references. Community of Chão de Estrelas, Recife, PE, January, 2012.

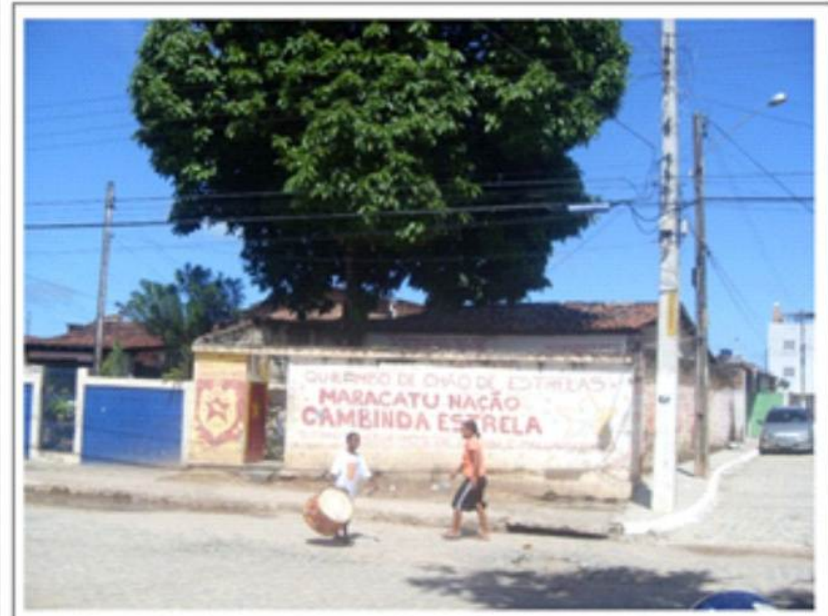

The headquarters of the Maracatus is a meeting place and space of construction of social ties around the cultural expression. On it occurs exchanging experiences and material and immaterial construction of Maracatu. It has important symbolic value in the neighborhood where it is located and is in the collective imaginary. Chão de Estrelas, June, 2011.

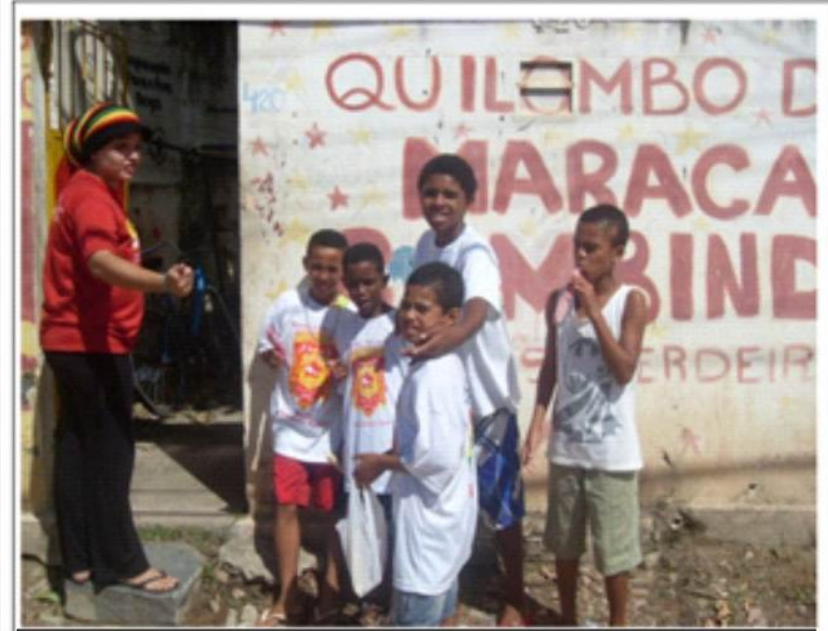

Children and teenagers find in the headquarters spaces of sociability and their identitarian references. The headquartes is a place of support, is «a fixed point» on the territory, to where movements and itineraries occur. Chão de Estrelas, June, 2011

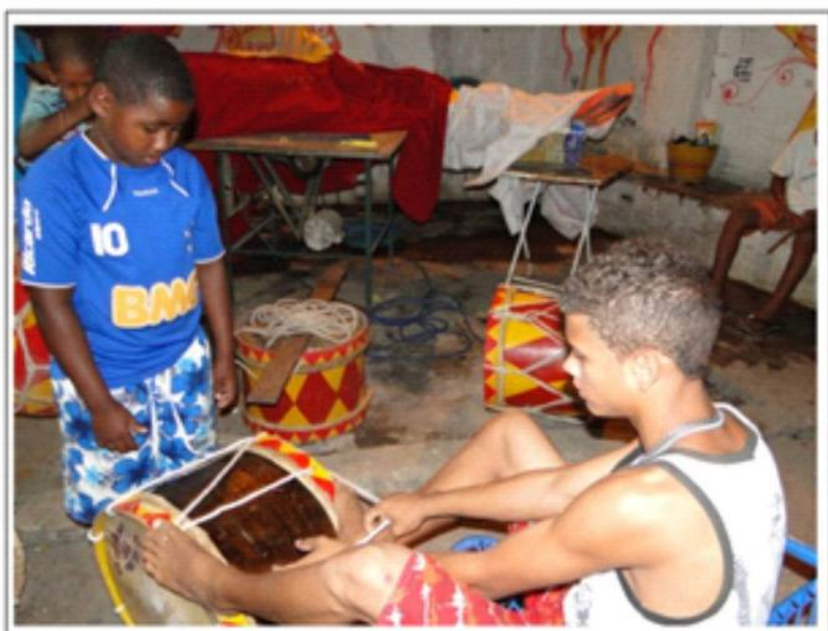

Fabrication and tuning of musical instruments - a knowledge transmited across generations communally and which happens in moment of intense communication and collective construction, and with the use of elaborated and recreated techniques in different contexs. Community of Chão de Estrelas, Recife, PE, February, 2012

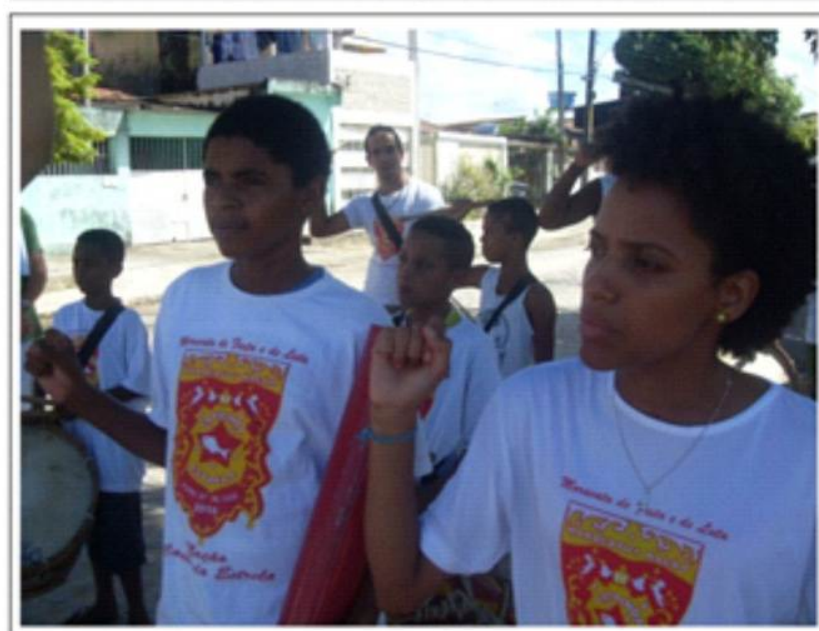

The African matrices are the main reference of Maracatus. The population of African origin when moved from central areas to occupy places whithout urban infrastructure, brought whith them their cultural practices, establishing its identity in neighborhoods and defining territorialities. Chão de Estelas, June, 2011.

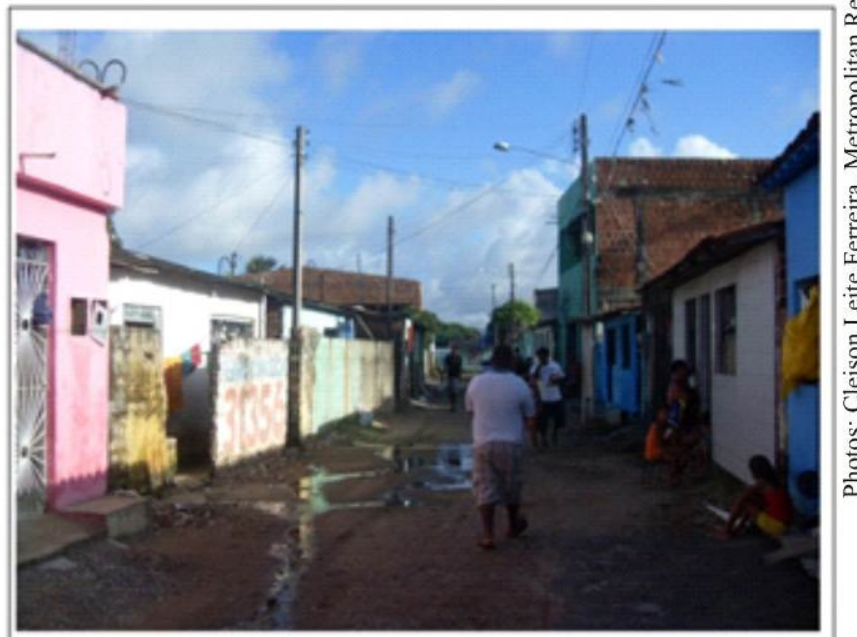

Each Maracatu extendes beyond the neighborhood where its headquarters is located, include other neighborhood or municipalities, such as of Maracatu Cambinda Estrela, from Chão de Estrelas (Recife), that has participants from the Community of Sotave, in Jaboatão dos Guararapes, PE, June, 2012. 


\subsection{Religious territoriality in the headquarters and on the streets of Recife - PE}

Maracatu-Nação was associated in its origin to Catholicism experienced by lay people, allowing a possible flexibility of their practices, leading them to join over the years to Xango, Umbanda, and Jurema religions. This occurred mainly by the persecutions against the Xango terreiros in Recife and the religious practices of people of African descent, who found in Maracatu a safe space where so camouflaged, accomplished their worship and religious obligations, which was gradually being incorporated into the procession and the manifestation itself. For the "doers" of Maracatu, the one that "does not fulfill religious obligations is not a real Maracatu. It is a folk group, is only a group of stage."

Currently it is common to the headquarters of Maracatus-Nação harboring also a Xango Terreiro devoted to Orixa and rooms in it to Caboclos and Masters of Jurema (religion of indigenous matrix) and the entities of Umbanda (Pomba-Gira, Preto-Velho) devotions. When does not happen this way there is at least one "room" where they are performed some religious a more individual obligations and with the intention of preserving the integrity of the participants of Maracatu-Nação.

The Maracatus-Nação perform religious obligations, whether in the Terreiro in common with headquarters, either in Terreiros in the communities, as a way of protection before going out to the streets (Figure 5). In addition, each Maracatu carries a representation of a spiritual entity, or an ancestor or "Egun", in the figure of the black doll - the Calunga (Photo 4), which also receives the obligations made in a room of the Terreiro called "Balé", and has a specific altar. The obligations are religious rituals that make up a shared secret among the members of the the Terreiro and Maracatus-Nação, and cannot be disclosed to non-participants of Xango. The obligations are also made for musical instruments, for the clothes and all the people who go out during courtship. It is well known, however, that when they need to talk about obligations for Calungas and other icons, they use terms like "we have already given food to the Calungas" or "this is where the Calungas eat and stay in the seclusion," but do not explain the ritual.

The Maracatus-Nação when go to the streets are provided with religious feeling and their passage will endow the space occupied by an identity based in the terreiros and headquarters. When entering a street with their calungas guided by Damas do Paço, the Maracatus define a territoriality full of symbols and cultural values. Damas do Paço are the guardians of the Calungas, and are the ones that only can tuch and carry them, so they should perform religious obligations (Figure 3).

A "time-space" quite significant for the Maracatus-Nação is the ritual "Night of the Silent Drums" that happens every year on the Monday of Carnival, in the Courtyard of the Rosary Church in the center of Recife. It is a ceremony in honor of Eguns when all Nations of Maracatu once they Eletronic Magazine: Time - Technical - Territory, V.3, N.1 (2012), 43:77 ISSN: 2177-4366 
have performed one by one, silence their drums at midnight and receive the presence of Babalorixás (Fathers of Saint) and Yalorixás (Mothers of Saint) (Photo 5 ) who pray in Yoruba in honor to African ancestors. So permeated with sacred and symbolic elements, the Courtyard of the Rosary Church (Catholic place of worship) is appropriate at that time and reframed as a sacred territory to religions of African origin. Its sacralization takes place with the presence of Calungas, Caboclos, Orixas, Fathers and Mothers of Saints, and many other elements which make up a religious territoriality, it means, they represent a set of social practices and symbolic in the sense of control and appropriation of territory "where the effect of the sacred power of faith reflects an identity and a sense of mutual ownership" (ROSENDAHL, 2005, p. 12934).

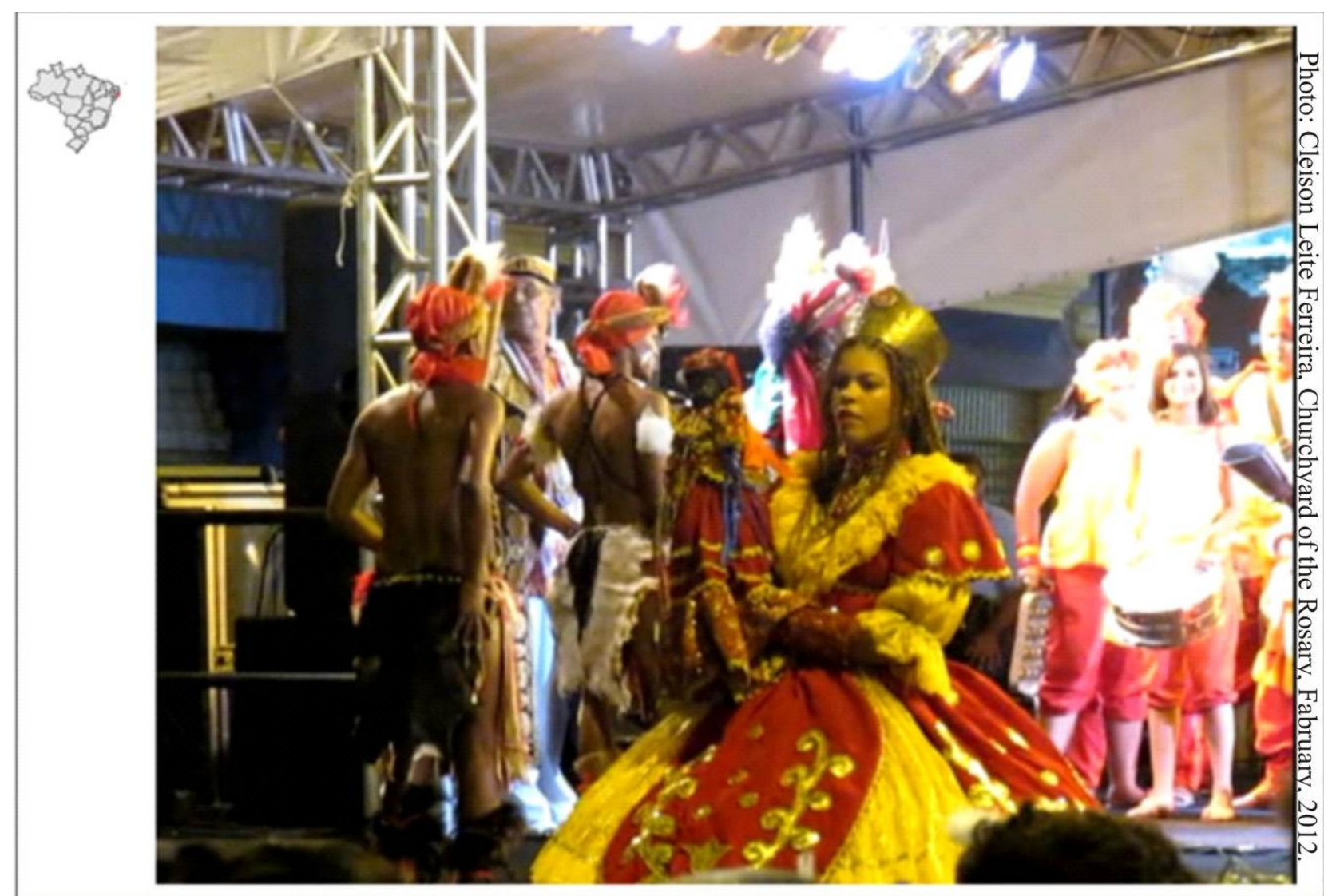

Foto 4: Dama do Paço (Lady of the Palace) of Maracatu-Nação Sol Nascente, from Água Fria - Recife, carrying the Calunga, in the Cerimony Night of the Silent Drums. This represents the religious and sacrad presence in the Maracatus-Nação. 


\section{Figure 5: Relationships beetween the Maracatus-Nação and the matrix African Religions}
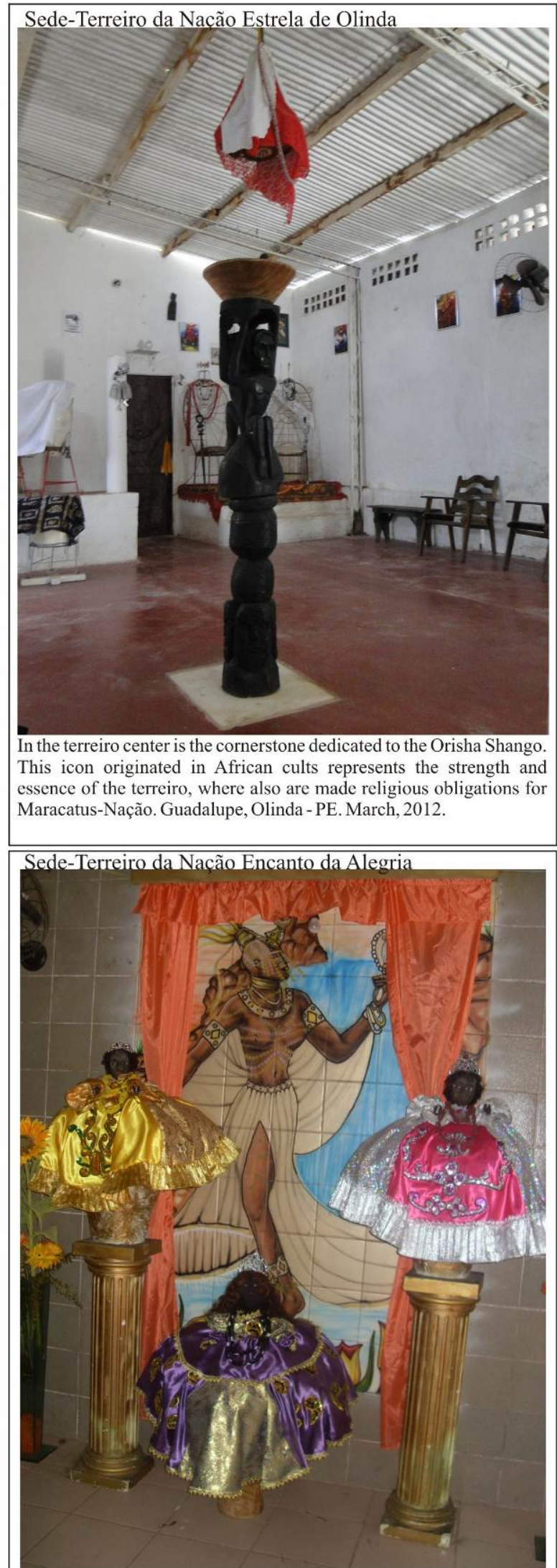

Calungas of Maracatu-Nação Encanto da Alegria in the Xango Terreiro. The Calunga representes Egun, it means ancestor. Without the Calunga any Maracatu goes out on the streets. She makes connection between the alive and dead and is the essence of Maracatu. Mangabeira, Recife. June - 2011 .

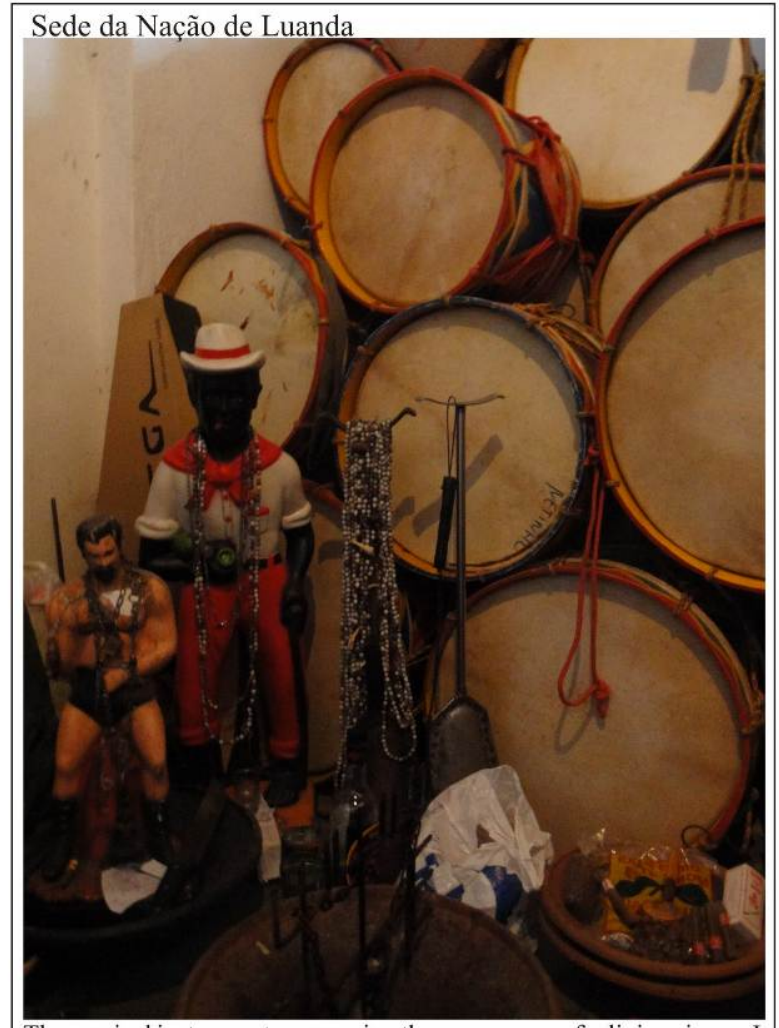

The musical instruments occupying the same space of religious icons. In this photo, alfaias and gonguês in the room dedicated to Jurema Religion, in the Maracatu-Nação de Luanda, Tabajara, Olinda - PE. March, 2012

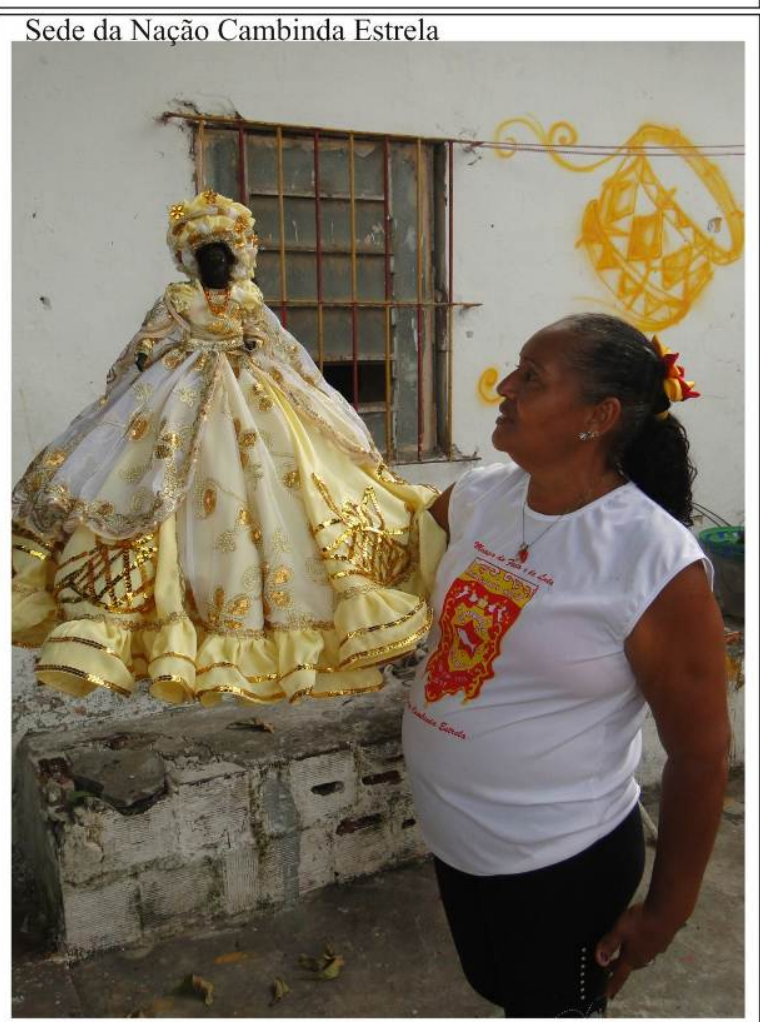

The only person allowed to touch the Calunga is the Lady of the Palace, who makes religious obligations for maintaining the integrity of all of the nation participants. «It's a responsability not for everyone», as says the guardian of the Calunga of Maracatu-Nação Cambinda Estrela. Chão de Estrelas. March, 2012. 


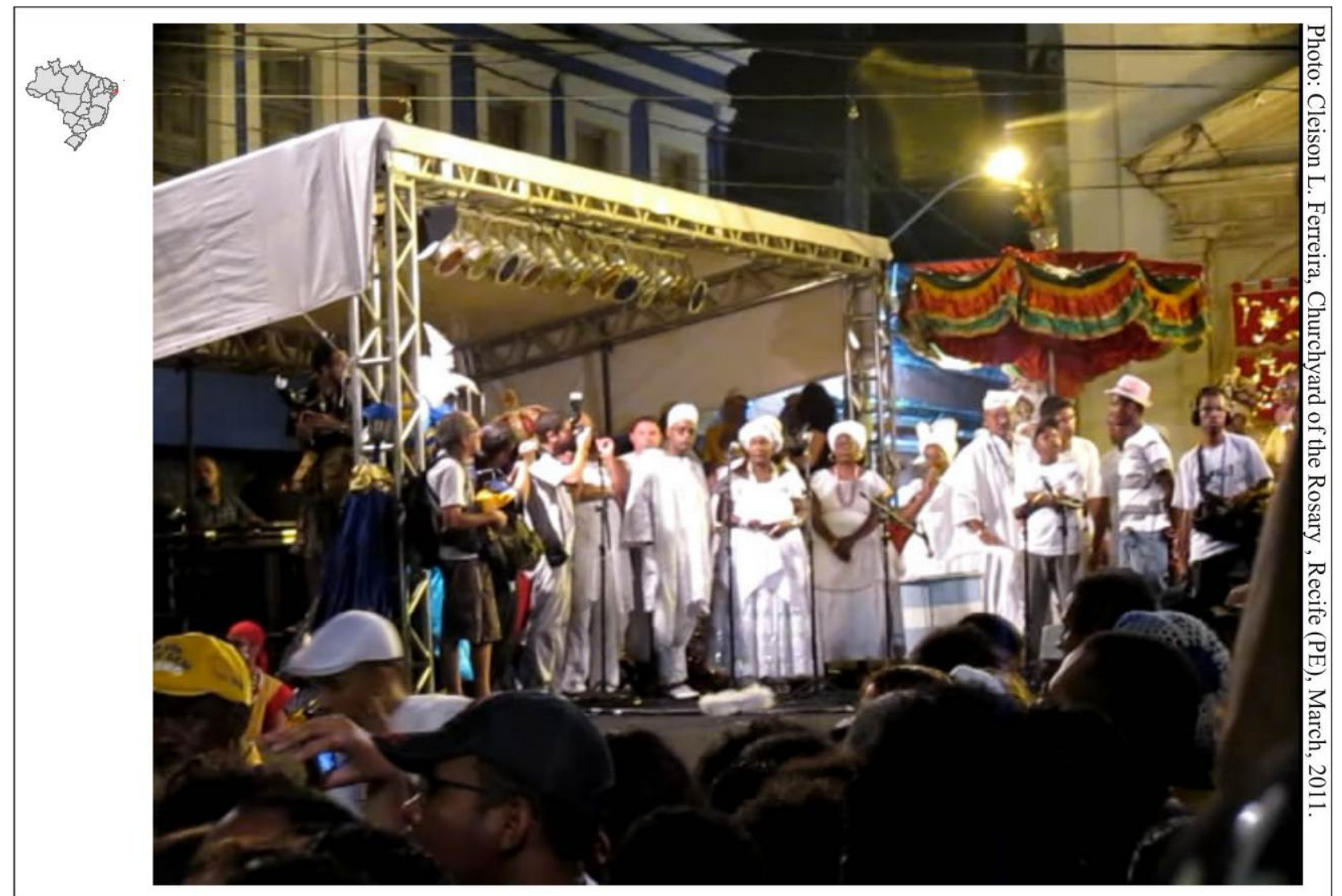

Foto 5: Babalorixás and Yalorixás, Priests of the Xango Religion, in the Cerimony Night of the Silent Drums, in the Churchyard of the Rosary, paying homage to Brazilian and African-Brazilian ancestors - the Eguns.

\section{MARACATUS-NAÇÃO OF PERNAMBUCO: HEADQUARTERS ORGANIZATION.}

We do not wish to identify or indicate patterns of organization of the headquarters of the Maracatus-Nação of Recife. This is because even with a common purpose, there are different peculiarities and situations that lead each Nation to make their spatial arrangement. In fieldwork we detected the following realities:

a) The headquarters is a residence and has no separate room to keep the material heritage, occupying bedrooms, living room, balcony;

b) The headquarters is a residence, but has a specific room to keep the material;

c) The Maracatu-Nação has its own headquarters, without Xango terreiro;

d) The Maracatu nation has its own headquarters where the material is stored and has a Xango Terreiro.

e) The headquarters of the Maracatu-Nação and the Xango Terreiro set up the same space

Below we represent graphically realities of two Maracatu-Nação headquarters, preserving some spaces due to the religious reasons cannot have its interior exposed, and in these cases their measurements and characterization were inferred and informed by the head of the Nation. 


\section{I- The Maracatu-Nação has its own headquarters, without Xangô Terreiro}

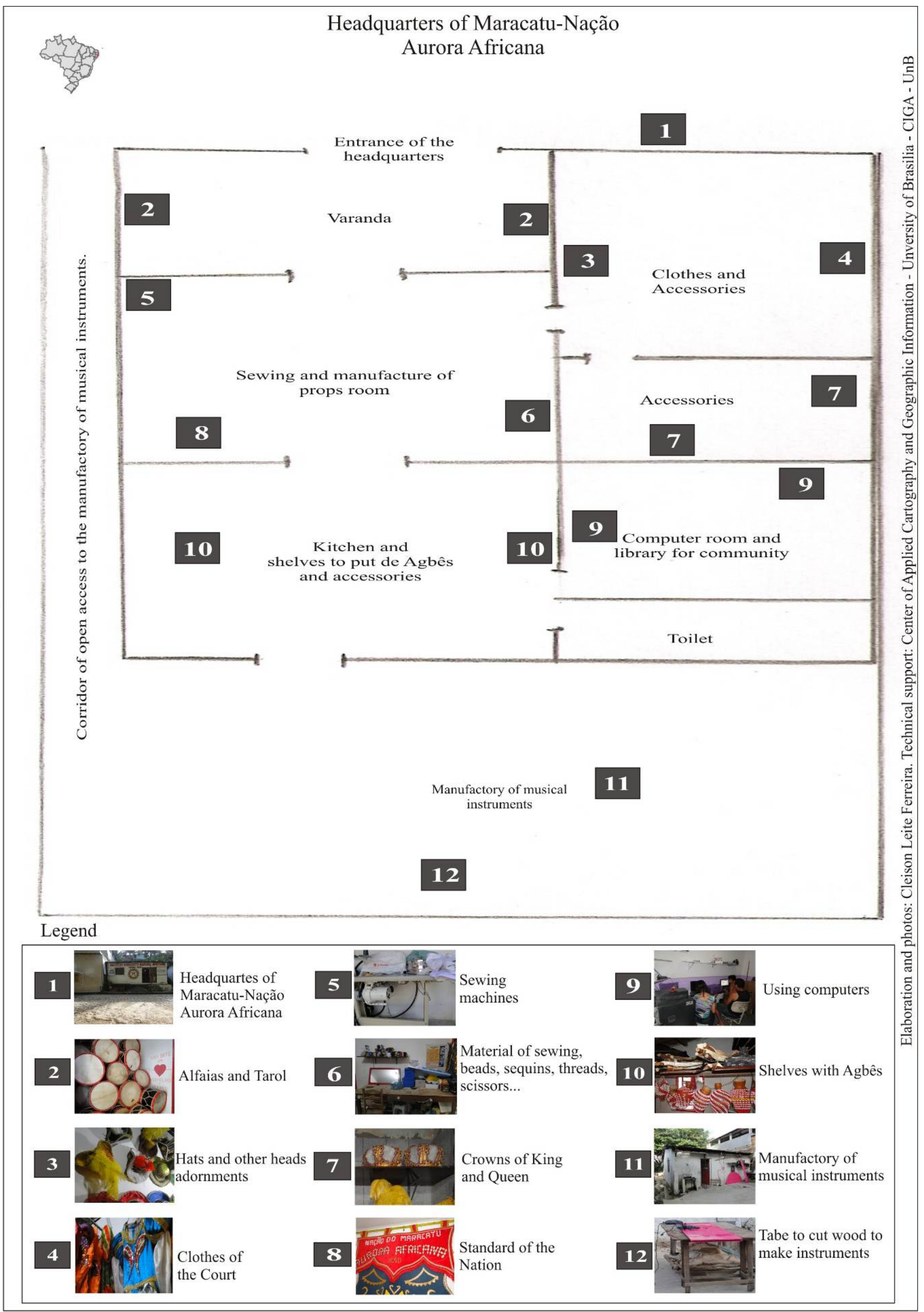

Eletronic Magazine: Time - Technical - Territory, V.3, N.1 (2012), 43:77 ISSN: 2177-4366 


\section{II- The Maracatu headquarters and the Xango Terreiro set the same spaces}

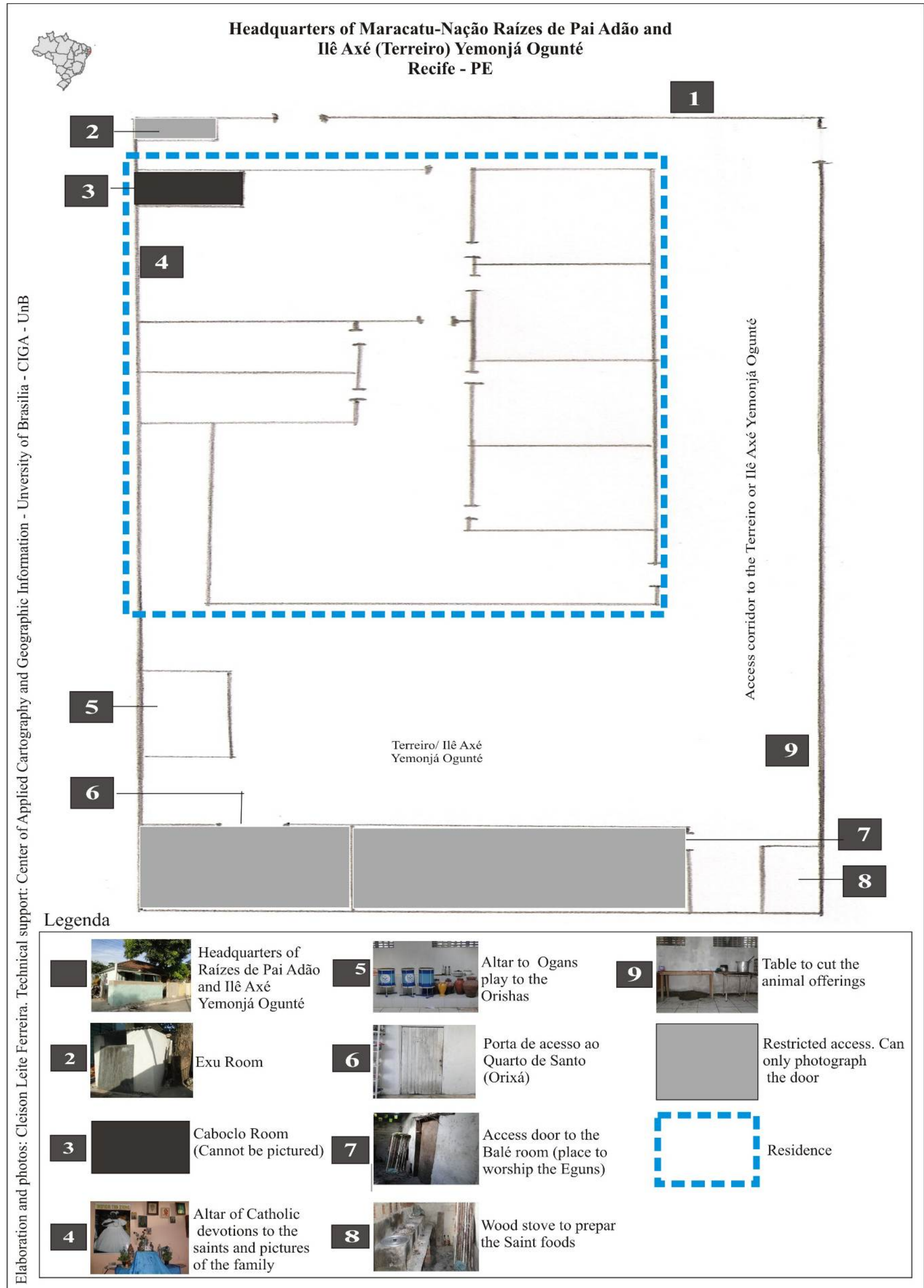

Eletronic Magazine: Time - Technical - Territory, V.3, N.1 (2012), 43:77 ISSN: 2177-4366 
Maracatus-Nação headquarters, having or not having a Xango Terreiro, do not disengage from the religion of African origin which serves both to legitimize themselves and affirm their traditions, reworking them as the context, needs and interests. This does not mean mischaracterization. Thus, there is no way to consider culture as an end in itself. According to Santos (2007):

Culture, way of communication of the individual and the group with the universe, is an inheritance, but also a relearning of the deep relations between man and his environment, a result obtained through the process of living itself. Including production process and social practice, culture is what gives us the feeling of belonging to a group, which is cement.

In the case of Maracatus-Nação this opening as adapting to the changes does not occur so alienating and passive. So much that elements considered traditional accompany them. Continuity does not mean linearity and repeatability. But being in the world and be seen requires consequences that shape in new ways and this is done consciously. It is also worth considering other words of Milton Santos:

Popular culture has its roots in the land where people live, symbolizes the human being and the environment, a willingness to face the future without breaking the continuity. Its frame and its limits are the deep relationships that weave between the man and the environment. So, since immunized against the trivialization that consumption among other reasons carries, uprooted people end up building a new popular culture that is both philosophy and therefore a path to freedom. (SANTOS, 2007, p. 86)

The headquarters of the Maracatus-Nação both may represent the link with the traditions when articulated with terreiros or have them in the same space and they can bring up the possibility of communication with the contemporary. In this movement they define territoriality in suburban communities and reverberate in the center, giving cultural identity to the whole.

\section{CONCLUSIONS AND RECOMMENDATIONS}

The social and cultural practices of the population of African origin in Brazil deserve more attention, mainly due to gaps still existing and resulting of years of ignored history. The population of African origin in Brazil has built and is building a legacy that involves an important social, political and economic organization, in many different spaces leaving significant ethnic and identitarian reference registered in the territory, and often concealed by both the government and the general population.

This study about the Maracatus-Nação of Pernambuco is the first step in an attempt to deepen the territorialities resulting from the population of African origin in Brazil. It is a preliminary interpretation, requiring an ongoing study. In this sense, we conclude and recommend that: 
- The Maracatus-Nação must be understood as cultural, social, and political practices. For being historical agents constructions they can not be seen only in its patrimonial and symbolic value, that paralyzes and condemns them to remain intact and neutral in the face of reality to which they belong - vision that puts them as allegories and a folkloric fact. If they are formed by social actors, and these are victims of an exclusive urban context, the Maracatus nation must be understood as claiming and visibility places, not as reproduction with no way out of the legacy of a past when the pain of slavery and the distance from Africa left them only a "toy" to resolve the suffering and nostalgia, as many folklorists and researchers thought and diffused.

- Significant territorialities are built in their neighborhoods where they are vulnerable to different adversities, but no more persecution of yore, but the abandonment of the public power. This situation makes their cultural aspects occupy the central areas of the city and impose their practice in the space, which certainly sets formation of territories. These become important by the fact that people with a history of persecution and spatial exclusion are able to articulate and maintain a unity permeated with common features that give a sense of belonging to a territorial basis, which is not "their" daily, but they appropriate, since the whole city, the state, the country, where they are part do not consider them in their processes. As said Anjos (2010), it is necessary that the population of African matrix in Brazil feel truly Brazilian.

- It is necessary that the government attends them in their demands; that the amounts they generate for the municipalities where they are part and for the very same state of Pernambuco can be reversed in specific public policies for the population of African origin, not so exclusivist but to acknowledge that such part of the population which is not minority, with a history of social and spatial exclusion and a present that sees not properly, needs affirmative action to correct the marks of the past and eliminate the racism still very much present in the context of the Metropolitan Region of Recife. Despite the festive moments put in evidence the population of African origin through Maracatus-Nação, it is necessary in its daily lives, in returning to its communities after the days of carnival or other presentations, it also can be seen and be in relevance to government actions.

- The Courtyard of the Rosary, the Xango Terreiros, and the neighborhoods made up of different ethnic references of African matrix represent territories where the population of African descent acquires, builds and lives its identity, but also in a symbolic and political dimension, give new meaning to the spaces, different of those experienced daily, providing identity to the whole. These spaces are community links, security in the face of adversities, a time of celebration and worship, recognition and a right of voice. And even with all the pressures, both terreiros of religions of African origin and Maracatus-Nação have significant force in the city spaces, due to outstanding personalities who were or are still ahead, and already occupying the collective imaginary such as Eletronic Magazine: Time - Technical - Territory, V.3, N.1 (2012), 43:77 ISSN: 2177-4366 
the ancestors of Dona Santa from Maracatu-Nação Elefante, Father of Saint Adão from Terreiro Ogunté Oba, the Tias (Aunts) of the Rosary Badia, Iaiá and Sinha, Master Luiz de França from Maracatu-Nação Leão Coroado, Mother of Saint Biu from Terreiro Santa Barbara, and the alive and working as Dona Marivalda from Maracatu-Nação Estrela Brilhante do Recife, Father of Saint Clóvis and Master Toinho both from Maracatu-Nação Encanto da Alegria, and Ivaldo Marciano from Maracatu-Nação Cambinda Estrela.

- Many terreiros and Maracatus-Nação blend with their own neighborhood where they are headquartered being ethnic, territorial, socio-spatial, and identitarian references, and bear in themselves the magnitude of which represents the overall population of African descent in Recife and Brazil as a whole. We must consider these spaces as heritages for the whole city, because they are imbued with the historical, cultural and human values built centuries by people of African origin, allowing a better appreciation and respect not only of cultural aspects, such as MaracatusNação and Religions but of all that population that articulates every day, despite the social and economic difficulties to keep alive their traditions and practices.

\section{BIBLIOGRAPHIC REFERENCES}

ANJOS, R. S. A. A África brasileira: população e territorialidade. Textos Básicos do CIGA, Ano 1, Número 1, 2010. 52 p.

Consultoria, 2011. 124 p.

Territiorialidade Quilombola: Fotos e Mapas. Brasília: Mapas Editora e

CORRÊA, R. L. Territorialidade e corporação: um exemplo. In: SANTOS, M; SOUZA, M. A. A.; SILVEIRA, L. S. (orgs) Território: Fragmentação e Globalização. São Paulo: HUCITEC/ANPUR, 2006. p. 251-256.

GUERRA-PEIXE, C. Maracatus do Recife. São Paulo: Irmãos Vitale, 1981. 173 p.

GUILLEN, I. C. M. Maracatus-nação, uma história entre a tradição e o espetáculo. In: GUILLEN, I. C. M. (org.) Tradições e Traduções: a cultura imaterial em Pernambuco. Recife: EdUFPE, 2008. p. 183-199.

PERNAMBUCO. Prefeitura da Cidade do Recife. Atlas de Desenvolvimento Humano do Recife, 2005.

ROSENDAHL, Z. Espaço e Religião: Uma abordagem Geográfica. Coleção Geografia Cultural, Rio de Janeiro, EdUERJ/NEPEC, 1996. 92p.

Território e territorialidade: uma perspectiva geográfica para o estudo da religião. In: X Encontro de Geógrafos da América Latina, Anais, São Paulo, USP, 2005.

SANTOS, M. O dinheiro e o território. In: SANTOS, M; BECKER, B. K. et. al. (orgs) Território, territórios - ensaios sobre o ordenamento territorial. Rio de Janeiro: DP\&A Editora, 2006. p. 13-21.

O Espaço do cidadão. São Paulo, EdUSP, 2007. 176 p. 
SOUZA, M. M. Reis Negros no Brasil Escravista - História da Festa de Coroação de Rei Congo. Belo Horizonte: EdUFMG, 2006. 387 p.

TINHORÃO, J. R. As Festas no Brasil Colonial, São Paulo: Editora 34, 2000. 176 p. 